\title{
Changes in sediment microbial diversity following chronic copper-exposure induce community copper-tolerance without increasing sensitivity to arsenic
}

\author{
Ayanleh MAHAMOUd AHMED ${ }^{a, b, c}[1]$, Vincent TARDY ${ }^{a, b}$ [1], Chloé BONNINEAU ${ }^{a}$, Patrick BILLARD ${ }^{d}$, \\ Stéphane PESCE ${ }^{a}$, Emilie LYAUTEY,b
}

a. INRAE, UR RiverLy, 69625 Villeurbanne, France

b. Univ. Savoie Mont Blanc, INRAE, CARRTEL, 74200 Thonon-les-Bains, France

c. Centre de Recherche, Université de Djibouti, BP 1904 Djibouti Ville, Djibouti

d . Université de Lorraine, LIEC, UMR7360, Vandoeuvre-lès-Nancy, 54501, France

[1] These authors have contributed equally to the work and are co-first authors

Received 4 November 2019, Revised 22 January 2020, Accepted 26 January 2020, Available online 1 February 2020.

Editor R. Debora

\section{Highlights}

- Sediment exposure to environmental Cu concentrations decreases microbial diversity.

- Large changes in community composition occurred, with fifty genera affected by Cu.

- Absolute abundance of the Cu resistance gene did not increase, but tolerance did.

- $\mathrm{Cu}$-induced changes generated diversity and functional costs at the community level.

- Costs of $\mathrm{Cu}$ adaptation did not increase community sensitivity to As toxicity.

\begin{abstract}
Sediment microbial communities were exposed for 21 days to an environmental concentration of copper to assess $\mathrm{Cu}$-induced composition changes and resulting effects on microbial sensitivity to acute $\mathrm{Cu}$ and As toxicity. Chronic $\mathrm{Cu}$ exposure reduced the diversity of the bacterial and archaeal communities from Day 0 to Day 21. The pollution-induced community tolerance concept (PICT) predicts that loss of the most sensitive taxa and gain of more tolerant ones should increase the capacity of $\mathrm{Cu}$-exposed communities to tolerate acute $\mathrm{Cu}$ toxicity. Although diversity loss and functional costs of adaptation could have increased their sensitivity to subsequent toxic stress, no increased sensitivity to As was observed. PICT responses varied according to heterotrophic activity, selected as the functional endpoint for toxicity testing, with different results for $\mathrm{Cu}$ and As. This suggests that induced tolerance to $\mathrm{Cu}$ and As was supported by different species with different metabolic capacities. Ecological risk assessment of contaminants would gain accuracy from further research on the relative contribution of tolerance acquisition and co-tolerance processes on the functional response of microbial communities.
\end{abstract}

\section{Keywords}

Co-tolerance; High-throughput sequencing; Microbial ecotoxicology; PICT; Resistance genes 


\section{Graphical abstract}

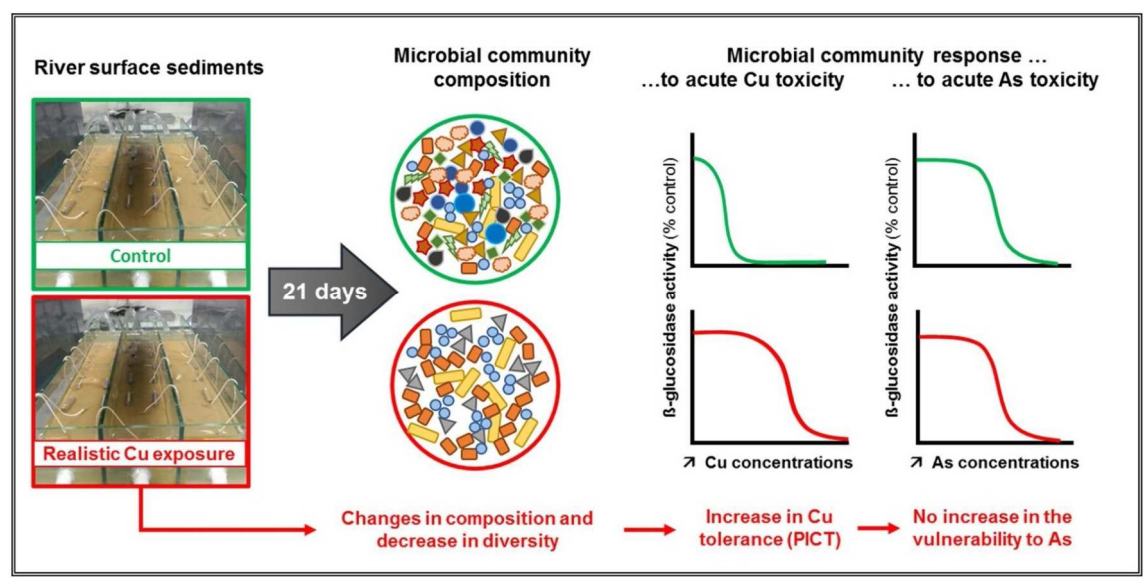

\section{Introduction}

Metals from natural and anthropogenic sources are ubiquitous in freshwater ecosystems (Bradl, 2005) both in solution and in particulates (Ancion et al., 2013; Rabiet et al., 2015). The sediments of lakes (Wang and Zang, 2014) and rivers (Ancion et al., 2013) are natural sinks for metals, including copper (Cu) and arsenic (As). Cu and As levels in contaminated sediments can reach concentrations of up to several hundred mg kg-1 dry weight (dw) (Farag et al., 1998, 2007; Ancion et al., 2013), exposing benthic communities to ecological risks (Wu et al., 2014). In sediments, MacDonald et al. (2000) proposed probable effect concentrations of $33 \mathrm{mg} \mathrm{kg-1} \mathrm{dw} \mathrm{and} 149 \mathrm{mg} \mathrm{kg-1} \mathrm{dw.} \mathrm{However,} \mathrm{ecological}$ risk assessment of metals (or other contaminants) in sediment is mainly based on the study of model organisms. Investigations at the community level of organization are still scant and relatively recent, especially for microbial communities (Gardham et al., 2014, 2015; Pesce et al., 2018a; Sutcliffe et al., 2018, 2019).

Microorganisms are highly abundant in sediments, where they contribute to many ecological functions including the recycling of autochthonous and allochthonous organic matter (Schwarz et al., 2007), the production of greenhouse gas through anaerobic processes such as denitrification (de Klein et al., 2017) and methanogenesis (Billard et al., 2015), and the biodegradation of organic contaminants (Ghattas et al., 2017). Recently, Mahamoud Ahmed et al. (2018) showed that environmental concentrations of $\mathrm{Cu}$ (i.e. about $40 \mathrm{mg} \mathrm{kg}-1 \mathrm{dw}$ ), alone or in a mixture with As at about the same concentration, can quickly impact the structure and a large set of functions of river benthic heterotrophic microbial communities. Structural changes following $\mathrm{Cu}$ exposure have also been observed in marine sediment bacterial communities (Gillan, 2004; Zhao et al., 2014). However, these studies were based on genetic fingerprinting approaches (such as PCR-ARISA or PCR-DGGE), precluding accurate assessment of diversity changes (Corcoll et al., 2019). Further studies using rRNA gene highthroughput sequencing confirmed these findings and revealed significant effects of $\mathrm{Cu}$ on the diversity and structure of benthic communities, eukaryote (Gardham et al., 2014; Yang et al., 2018), fungal (Sutcliffe et al., 2019) and prokaryote (Yang et al., 2018; Sutcliffe et al., 2019).

Several studies performed with natural periphytic assemblages, which grow on the surface of immersed substrates such as cobbles and rocks, have demonstrated that $\mathrm{Cu}$-induced shifts in microbial community diversity and structure generally co-occur with an increased community tolerance to $\mathrm{Cu}$ (Tlili et al., 2010; Lambert et al., 2012; Corcoll et al., 2019). This exemplifies the concept of pollutioninduced community tolerance (PICT), first introduced by Blanck et al. (1988). The PICT concept postulates that chronic exposure to pollutants exerts a selection pressure on exposed communities, eliminating the most sensitive species and promoting the most resistant ones. According to Tlili et al. 
(2016), this community structure change toward a dominance of tolerant species can be assessed in the laboratory by measuring responses of physiological endpoints in acute short-term bioassays and by comparing the responses of a reference community with those of a chronically pre-exposed one. At the cell level, microbial resistance to $\mathrm{Cu}$ can involve several non-exclusive mechanisms including exclusion by permeability barrier, intra- and extra-cellular sequestration, active transport efflux pumps and enzymatic detoxification (Bruins et al., 2000). The efflux ATP-ase pump CopA, and the resistancenodulation-division (RND) protein CusA, both able to extrude excess $\mathrm{Cu}$, are among the well-known proteins that mediate microbial resistance to $\mathrm{Cu}$ (Franke et al., 2003). PICT thus relies on several adaptation processes at both individual level (through physiological or genetic adaptation) and community level (through the loss of sensitive species) (Blanck and Dahl, 1996).

Many successful studies using PICT with periphytic microbial communities show that PICT is a powerful tool for ecological risk assessment of contaminants in aquatic ecosystems (Tlili et al., 2016; Pesce et al., 2016). However, to our knowledge, the study of Olgivie and Grant (2008) is the only one that has applied PICT to sediment microbial communities. Using thymidine and leucine incorporation as endpoints for $\mathrm{Cu}$ tolerance measurements in estuarine sediment communities, a strong positive correlation was shown between $\mathrm{Cu}$ tolerance levels and pore water $\mathrm{Cu}$ concentration. By contrast, no correlation was detected between microbial community structure and community tolerance (Olgivie and Grant, 2008). The in situ adaptation of microbial communities to $\mathrm{Cu}$ in this compartment has been demonstrated through the study of microbial Cu-resistant genes. Besaury et al. (2013) showed that the total abundance of copA and the relative abundance of copA and cusA in microbial communities from Chilean coastal marine sediments increased significantly in the most Cu-contaminated locations ( $>1400 \mathrm{~g} \mathrm{Cu} \mathrm{kg}-1 \mathrm{dw}$ ). Studying marine and river sediment samples with contrasting levels of metal contamination, Roosa et al. (2014) also observed a significant positive correlation between the abundance of copA and the concentration of the easily exchangeable $\mathrm{Cu}$ fraction. In these natural sediments, the abundance of $\mathrm{Cu}$ resistance genes was also found to be positively correlated with other metals, such as As, Cr or Al in the easily exchangeable fraction. Using a PICT approach, Tlili et al. (2011) demonstrated that heterotrophic periphytic microbial communities chronically exposed to Cu became more sensitive to As acute toxicity, suggesting a negative co-tolerance between these metals (Vinebrooke et al., 2004).

Gaining a better understanding of the influence of positive and negative co-tolerance processes and finding the rules governing the response of microbial communities to contaminants remains an important challenge for improving ecological risk assessment by considering the role of biodiversity in community sensitivity and ecosystem stability (Vinebrooke et al., 2004; Tlili et al., 2016; Ye et al., 2017, 2019).

Research is needed to characterize the mechanisms that drive metal-induced tolerance and cotolerance in sediment microbial communities. Testing a 21-day realistic scenario for exposure to $\mathrm{Cu}$ (nominal concentration of $40 \mathrm{mg} \mathrm{kg-1} \mathrm{dw}$, which is representative of high levels of Cu contamination in French freshwater sediments (INERIS, 2010)), we recently showed in a laboratory channel experiment that natural river sediment microbial communities were structurally and functionally impaired by $\mathrm{Cu}$ (Mahamoud Ahmed et al., 2018). In the present study, we sought to expand these findings by characterizing changes in diversity, resistance and tolerance of sediment microbial communities subjected to chronic $\mathrm{Cu}$ exposure, and the resulting sensitivity to exposure to another metal. Our specific aims were to assess (i) Cu-induced changes in both the diversity of archaeal and bacterial communities and their genetic resistance potential against $\mathrm{Cu}$, and (ii) resulting effects on their sensitivity to acute $\mathrm{Cu}$ and As toxicity. 
In line with the PICT concept, we show that chronic exposure to $\mathrm{Cu}$ increased the community tolerance to acute $\mathrm{Cu}$ toxicity following changes in the community composition (due to shifts from sensitive to tolerant species) and concomitantly increased relative abundance of Cu-resistance genes. By contrast, (at variance with previous findings (Tlili et al., 2011)), tolerance to acute As toxicity remained unchanged or even increased depending on the toxicity assay used, reflecting the complexity of metal co-tolerance mechanisms in microbial communities.

\section{Materials and methods}

\subsection{Experimental set-up and physical-chemical analyses}

The experimental set-up, including the spiking procedure and the methods used for physical-chemical analyses of water and sediment, is detailed in Mahamoud Ahmed et al. (2018).

Briefly, the experiment was conducted for 21 days in six laboratory glass channels filled with $3.5 \mathrm{~kg}$ of $2 \mathrm{~mm}$ sieved river sediment (naturally containing about $2 \mathrm{mg} \mathrm{kg}-1 \mathrm{dw}$ and $3 \mathrm{mg} \mathrm{kg}-1 \mathrm{dw}$ ) collected at the Pont-de-Chazey sampling station (latitude N $45^{\circ} 54^{\prime} 38^{\prime \prime}$, longitude E $5^{\circ} 14^{\prime} 11^{\prime \prime}$ ) on the Ain river (France) and $6 \mathrm{~L}$ of uncontaminated recirculating water. Sediment was spiked (CU treatment, three replicates) or not ('REF' treatment, three replicates) with $\mathrm{Cu}$ at a targeted nominal concentration of 40 mg kg-1 dw.

Sediment particle-size classes (70\% of $250-300 \mu \mathrm{m}$ particles, $18 \%$ of $70-80 \mu \mathrm{m}$ particles, $2 \%$ of $10-20$ $\mu \mathrm{m}$ particles, $<1 \%$ clays and $8 \%$ silts) were determined before spiking. Water temperature $(19.2 \pm 0.2$ $\left.{ }^{\circ} \mathrm{C}\right), \mathrm{pH}(8.2 \pm 0.9)$, conductivity $(230.0 \pm 8.8 \mu \mathrm{S} \mathrm{cm}-1)$ and dissolved oxygen concentrations $(8.2 \pm 1.9$ $\mathrm{mg} \mathrm{L-1}$ ) were determined at the start of the experiment and after 7,14 and 21 days of exposure $(\mathrm{n}=$ 24). No significant difference between treatments or between sampling dates was found at any time during the experiment (Mahamoud Ahmed et al., 2018).

The measured concentration of $\mathrm{Cu}$ in the spiked sediment and in the overlying water respectively decreased from about $56 \mathrm{mg} \mathrm{kg-1}$ dw to about $46 \mathrm{mg} \mathrm{kg-1} \mathrm{dw} \mathrm{(Mahamoud} \mathrm{Ahmed} \mathrm{et} \mathrm{al.,} \mathrm{2018)} \mathrm{and}$ from about $60 \mu \mathrm{g} \mathrm{L-1}$ to about $39 \mu \mathrm{g} \mathrm{L-1}$ (Pesce et al., 2020) in the 21 days of exposure.

\subsection{Real-time PCR assays}

Sediment samples for molecular analyses $(n=24)$ were collected in each channel the start of the experiment in the channels do (i.e. $20 \mathrm{~h}$ after the spiking procedure, see Mahamoud Ahmed et al. (2018)), and after 7 (d7), 14 (d14) and 21 (d21) days of exposure in the channels, and were immediately stored at $-20{ }^{\circ} \mathrm{C}$ until DNA extraction. Microbial sediment DNA was extracted from $0.5 \mathrm{~g}$ of wet sediment using a NucleoSpin Soil Kit (Macherey-Nagel EURL) following the manufacturer's instructions and using SL1 lysis buffer and additive Enhancer SX buffer. The extracted DNA was quantified fluorometrically after staining with QuantiFluor dsDNA Dye (QuantiFluor dsDNA System, Promega) using a Plate Chameleon ${ }^{\text {TM }}$ fluorometer (Hidex; excitation 485 nm, emission 590 nm).

Real-time PCR quantification of bacterial 16S rRNA gene abundance was carried out using primers 968 $\mathrm{F}$ and 1401R according to Cébron et al. (2008). For the quantification of cusA (membrane copper transport protein), the primer pair cusF1/cusR2 (5'-GGACGAGGGCGACCTGMTGTAYATGCC-3'/5'GGGTCTTGATGCCGGTGGMSAGCATRTC-3') was used. Quantification of arsB and acr3 (arsenite transporters) was carried out using primer pairs darsB1F/darsB1R and dacr1F/dacr1R (Poirel et al., 2013). Reactions took place in a total volume of $20 \mu \mathrm{L}$ containing $1 \times$ iQ SYBR Green Supermix (BioRad), $0.4 \mu \mathrm{M}$ of each primer, $0.6 \mu \mathrm{g} \mu \mathrm{L}-1$ of bovine serum albumin, $0.08 \mu \mathrm{L}$ of $\mathrm{T} 4$ bacteriophage gene 32 product (QBiogene) Master Mix, $0.3 \mathrm{mg} \mathrm{mL}-1 \mathrm{BSA}$ (Sigma-Aldrich), each primer, and $4 \mu \mathrm{L}$ of template DNA. Standard ranges were plotted from 10 -fold serial dilutions of plasmid solutions 
containing the gene of interest. Cycling conditions were as described in Poirel et al. (2013) for amplification of arsB and acr3, and as follows for cusA: $95^{\circ} \mathrm{C}$ for $5 \mathrm{~min}$, followed by 50 cycles each of $95{ }^{\circ} \mathrm{C}$ for $30 \mathrm{~s}, 56^{\circ} \mathrm{C}$ for $30 \mathrm{~s}, 72{ }^{\circ} \mathrm{C}$ for $30 \mathrm{~s}$ and a final extension step of $7 \mathrm{~min}$ at $72{ }^{\circ} \mathrm{C}$. All runs were performed in an iCycler iQ system (Bio-Rad) associated with iCycler Optical System Interface software (version 2.3, Bio-Rad).

The quantification of copA (copper efflux system) was carried out according to Roosa et al. (2014) using the copA-F / copA-R primer pair, but no amplification was obtained despite several attempts to adapt the published protocol.

\subsection{High-throughput 165 rRNA gene sequencing and bioinformatic analysis}

PCR amplification for high-throughput 16S rRNA gene sequencing was carried out with the universal primer pair $515 \mathrm{~F}$ (5'-GTGYCAGCMGCCGCGGTA-3') and 909R (5'-CCCCGYCAATTCMTTTRAGT-3') targeting the V4-V5 hypervariable region of the $16 \mathrm{~S}$ rRNA gene (Wang and Qian, 2009). Indexes were integrated to both primers following the dual-indexing procedure described by Kozich et al. (2013). Triplicate PCR amplification for each sample was carried out with a total amount of $\sim 5 \mathrm{ng}$ of DNA per reaction. Amplicon products were quantified using Picogreen assay (Life Technologies, Carlsbad, USA) and pooled equimolarly. The final pool was purified with CleanPCR beads (CleanNA). Sequencing was done by Fasteris (Geneva, Switzerland) on an Illumina HiSeq system with $2 \times 300 \mathrm{bp}$. The analysis yielded $7.5 \mathrm{~Gb}$ of sequences with an average error rate of $0.822 \%$, and average Q30 of $90.3 \%$. Adapters were removed using Trimmomatic (Bolger et al., 2014) and barcodes sorted using a Fasteris internal script. Sequences were then processed using the FROGS (Find Rapidly OTUs with Galaxy Solution) Galaxy-supported pipeline (Escudié et al., 2018). Paired-end reads were joined using FLASH (Magoč and Salzberg, 2011) and a quality check was performed using FastQC. Sequences with primers having no mismatch were kept. They were then filtered by size (350-500 bp) and those containing $\mathrm{N}$ bases were discarded. The $16 \mathrm{~S}$ rRNA gene sequences were then denoised and clustered using the Swarm method (Mahé et al., 2015) with a three-base maximum difference, deletion of clusters with less than $0.005 \%$ abundance and cluster occurrence in a minimum of two samples of the total library. Chimeras were removed using vchime of vsearch package (Rognes et al., 2016). Affiliation was done using the Silva SSU database 123 (Quast et al., 2013) through BLAST (Altschul et al., 1990) with allowed multiple affiliation and manual curation. All analyses were done on the Galaxy instance of the INRA MIGALE bioinformatics platform (http://migale.jouy.inra.fr). Sequences are available at GenBank under submission number PRJNA589240.

\subsection{Acute toxicity tests to determine pollution-induced community tolerance (PICT) and co- tolerance measurement}

To assess the tolerance of heterotrophic communities to $\mathrm{Cu}$ and to As, short-term toxicity tests were performed at Day 21 with the two metals, tested individually, using the extracellular enzymatic activities $\beta$-Glu (EC 3.2.1.21), Lap (EC 3.4.11.1) and Pase (EC 3.1.3.1) as endpoints. Activity measurements were respectively made using the fluorescent-linked substrates 4-methylumbelliferylß-d-glucopyranoside (MUF-Glu, CAS No. 18997-57-4, Sigma-Aldrich), I-leucine-7-amido-4methylcoumarin hydrochloride (MCA-Leu, CAS No. 62480-44-8, Sigma-Aldrich) and 4methylumbelliferyl phosphatase (MUF-P, CAS No. 3368-04-5, Sigma-Aldrich), using a protocol adapted from Foulquier et al. (2013). The optimal substrate concentrations (1000 $\mu \mathrm{M}$ for $\beta$-glu, $1333 \mu \mathrm{M}$ for LAP and $500 \mu \mathrm{M}$ for Pase) were determined beforehand. 
Logarithmic dilutions of $\mathrm{CuSO} 4.5 \mathrm{H} 2 \mathrm{O}$ and $\mathrm{AsNaO} 2$ solutions were made with demineralized water to obtain five nominal concentrations of $\mathrm{Cu}$ and of As ranging from 1 to 10,000 mg L-1. Sediment communities (1.2 g wet sediments) were exposed for $4 \mathrm{~h}$ to $1 \mathrm{~mL}$ of each dilution, in the dark with gentle shaking, at room temperature (about $23^{\circ} \mathrm{C}$ ). For each sample replicate, two blanks (i.e. without $\mathrm{Cu}$ ) and one analytical sample were analyzed for each acute exposure level concentration.

The activities were stopped with $0.3 \mathrm{~mL}$ of glycine buffer ( $\mathrm{pH} 10.4$, glycine $0.05 \mathrm{M}$ and NH4OH $0.2 \mathrm{M}$ ) before centrifugation (at $5000 \times \mathrm{g}$ for $5 \mathrm{~min}$ ), and fluorescence was measured using a microplate reader (Synergy HT BioTek Instruments) with excitation wavelength set to $360 \mathrm{~nm}$ and emission wavelength set to $460 \mathrm{~nm}$. Enzymatic activity was quantified using standard curves of the reference compounds: MUF (for $\beta$-glu and Pase, Sigma M1381 CAS No. 90-33-5) and MCA (for LAP; Sigma A9891, CAS No. 26093-31-2).

\subsection{Data processing}

After confirming normality of the residuals (Shapiro-Wilk test; Royston, 1982) and data homoscedasticity (Fligner-Killeen test; Conover et al., 1981), significant differences between treatments in the abundance of metal resistance genes and diversity indices were sought by analysis of variance (ANOVA) and further analyzed with a post hoc Tukey test. Differences were considered statistically significant when the $p$ value was below 0.05 . Differences in prokaryotic community structure between treatments were characterized using UniFrac distance (Lozupone and Knight, 2005). Nonmetric multidimensional scaling (NMDS) was used to graphically depict differences between the bacterial communities. The significance of the observed clustering of samples on the ordination plot was assessed by analysis of variance using distance matrices (ADONIS test, 999 permutations). We used the R package "DESeq2" (Love et al., 2014) to calculate the significant changes in prokaryotic composition (log2-fold change in relative abundance of each OTU) between treatments (REF vs. CU) at each sampling time. OTUs were considered significantly differently abundant between treatments if their adjusted $\mathrm{p}$ values were $<0.01$. All these statistical analyses were performed with the $\mathrm{R}$ free software (version 3.4.3, R Core Team, 2018).

The results of the acute toxicity assays were used to model dose-response curves and retrieve toxicity threshold values using the R package drc (Ritz et al., 2015). For each channel and each extracellular enzyme tested, activities were expressed in percentage of the activity of the uncontaminated control assay. Copper concentrations ( $\mathrm{mg} \mathrm{Cu}$. $\mathrm{kg}-1 \mathrm{dw}$ ) were derived from the measured dissolved copper concentration and the weight of the dry sediment used in the test. For each treatment, a best-fit model procedure was used to select, from different models (Weibull, log-logistic, Brain-Cousens), the one that best fitted the data from the three independent channels, based on the Akaike Information Criterion (AIC; Akaike, 1974) and visual inspection of residuals and fitted data. Thereafter, EC50 and corresponding 95\% confidence interval were calculated using either asymptotic-based or logarithm scale-based confidence intervals (package drc, Ritz et al., 2015). Differences between EC50 were considered significant $(p<0.05)$ when no overlapping of the confidence intervals was observed (Scheffczyk et al., 2014).

\section{Results}

\subsection{Effect of chronic exposure to Cu on bacteria and archaea community diversity, structure, and composition}

High-throughput sequencing of the 16S rRNA gene approach applied in the present work recovered 1938 OTUs affiliated to both the archaea and bacteria domains. Both richness and Shannon-Wiener 
diversity index (Fig. 1) were stable, at around 1742 OTUs and $\mathrm{H}^{\prime}=6.3$ in the REF sediments throughout the experiment. The $\mathrm{Cu}$ treatment produced a rapid, significant and persistent decrease in both the OTU richness (with a decrease down to 1434 OTUs) and the Shannon-Wiener diversity index, with a marked decrease $\left(H^{\prime}=4.41\right)$ at Day 7, followed by a slight recovery $\left(H^{\prime}=5.4\right)$ at Days 14 and 21.

Fig. 1. Observed OTU richness $(A)$ and Shannon diversity index (B) in uncontaminated (REF) and Cu-spiked (CU) sediments at Days 0 (i.e. 20 $\mathrm{h}$ after spiking), 7, 14 and 21 . For each sampling time, asterisks indicate significant differences between treatments, according to Fisher test $(* \mathrm{p}<0.05 ; * * \mathrm{p}<0.01 ; * * * \mathrm{p}<0.001)$.

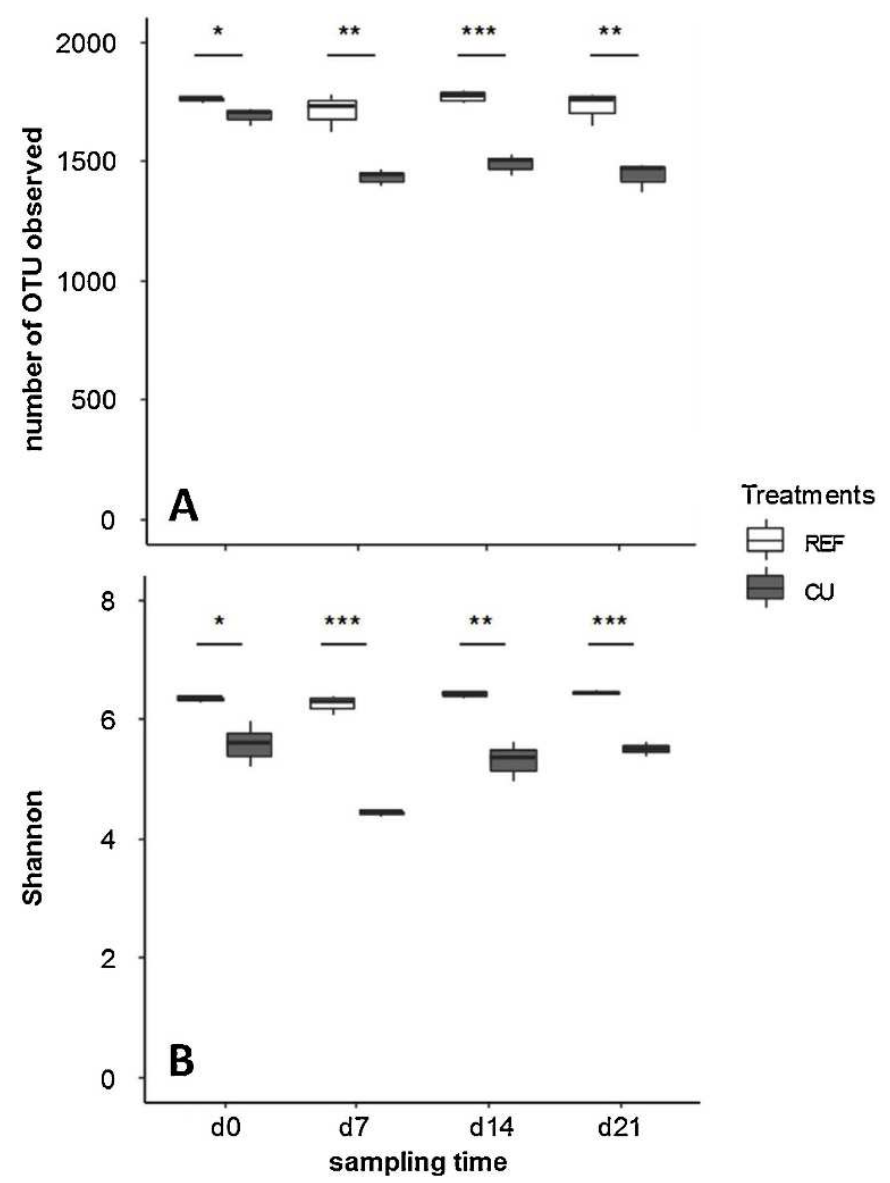

NMDS analysis of the full sequence datasets discriminated the structure of prokaryotic communities according to treatment and sampling time (Fig. 2). The main parameter discriminating communities was "Cu treatment", with significantly distinct structures observed through the experimental period and confirmed by ADONIS test (ADONIS test: $R^{2}=0.45$ and $p<0.001$ ). Results also showed a temporal evolution of prokaryotic communities (ADONIS test: $R^{2}=0.24$ and $p<0.001$ ), especially for the $\mathrm{Cu}$ treated community with samples at Day 0 (i.e. $20 \mathrm{~h}$ after spiking) clustering with the REF sample communities, whereas communities exposed to Cu for 7 days and for 14 and 21 days clustered out.

Fig. 2. Non-metric multidimensional scaling (NMDS) ordination plot derived from weighted pairwise UniFrac distances of both uncontaminated (REF) and Cu-spiked (CU) sediments at Days 0 (i.e. $20 \mathrm{~h}$ after spiking), 7, 14 and 21. Stress values for ordination plot were $<0.2$, which indicates that these data were wellrepresented by the twodimensional representation.

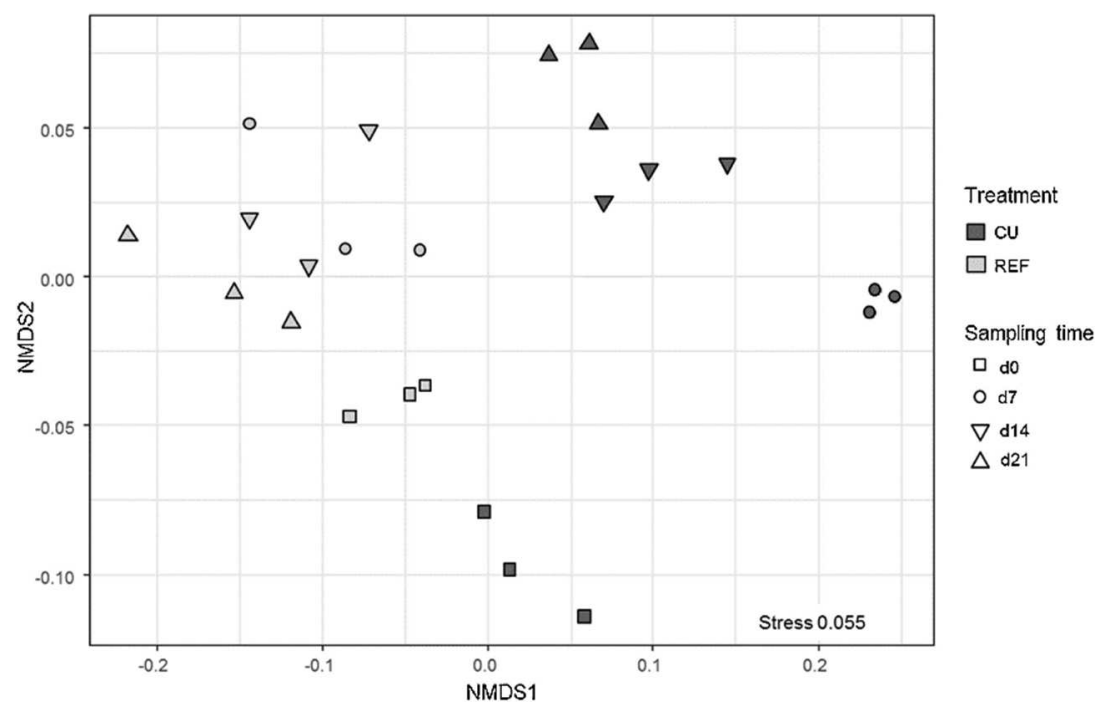


A DESeq2 analysis on the more representative OTUs (191 in all) identified 55 bacterial genera accounting for the differences between the REF and Cu-exposed communities through the experimental period (Fig. 3). At Day 0 (i.e. $20 \mathrm{~h}$ after spiking), results highlighted early significant changes in community composition, with a large increase in OTUs affiliated to the phylum Bacteroidetes ( $+6.9 \%$ of total sequences) within which Flavobacterium was the most abundant genus (+ 5.6\% of total sequences). From 7 to 21 days, large changes in composition occurred within $\mathrm{Cu}$ treated communities, with a significant increase in OTUs affiliated to Proteobacteria $(+10-15 \%$ of total sequences) and Bacteroidetes phyla ( $+6-15 \%$ of total sequences). Among these two bacterial phyla, OTUs affiliated to the genera Flavobacterium, Limonhabitans, Novosphingobium, Methylophilus, Rhizobacter and Zooglea increased most in abundance within Cu-treated communities (more than $1 \%$ of total sequences). Conversely, OTUs affiliated to the phyla Actinobacteria, Chloroflexi, Cyanobacteria and Planctomycetes decreased significantly in abundance from 7 days and until the end of the experiment (Fig. 3).

Fig. 3. Log2-fold change in relative abundance of genera between Cu-spiked (CU) sediments compared to uncontaminated ones (REF) at Days 0 (i.e. $20 \mathrm{~h}$ after spiking), 7, 14 and 21. Each square represents a single OTU and the size of square represents the abundance of OTU in full datasets. Dashed lines represent the limit of significant increases (positive values) or decreases (negative values) in abundances of OTUs. Only OTUs contributing to $>1 \%$ of total sequences were considered.

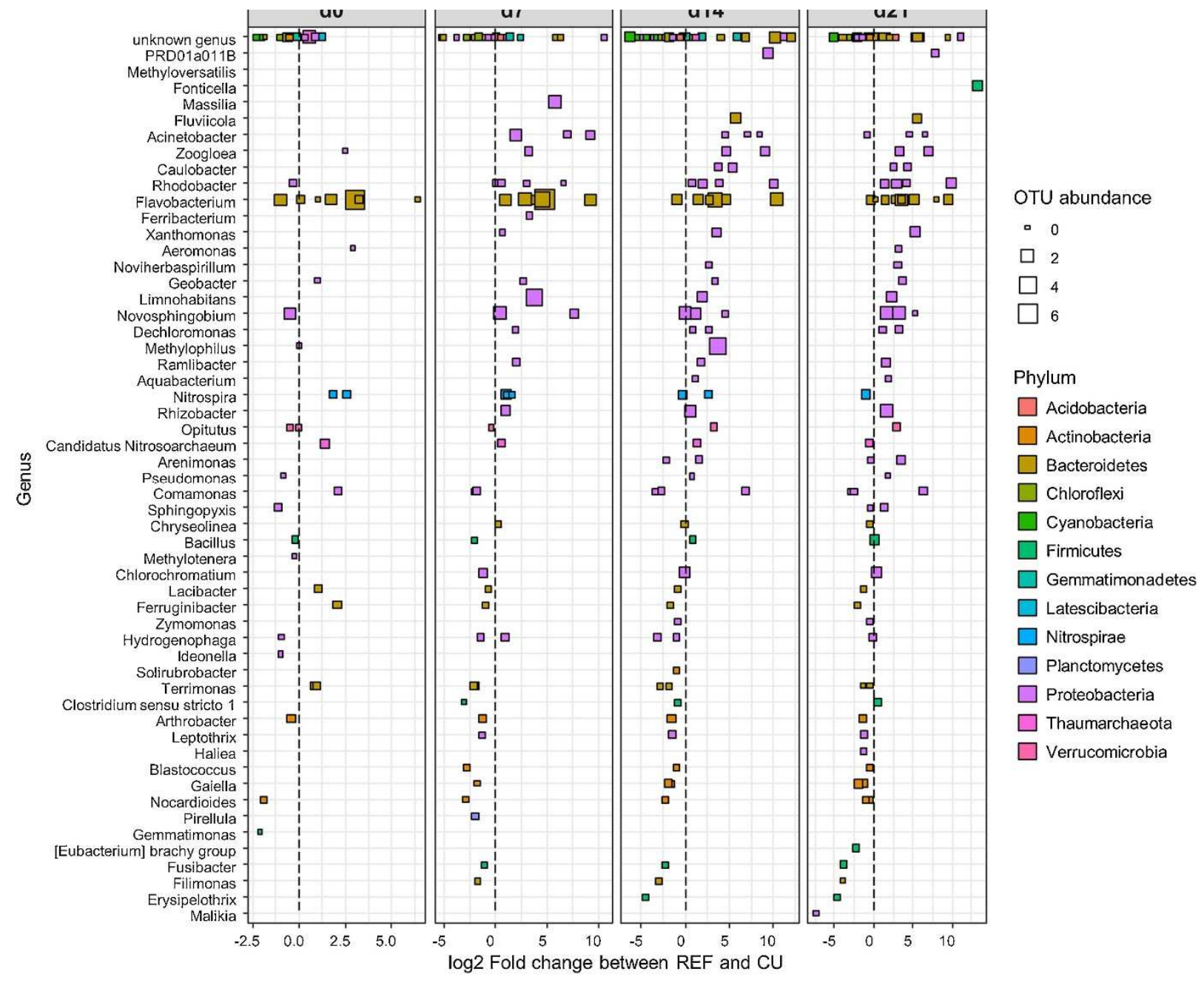




\subsection{Effect of chronic exposure to $\mathrm{Cu}$ on the abundance of $\mathrm{Cu}$-and As-resistance genes}

Despite several attempts to adapt the published protocol in our laboratory, amplification of the targeted copA gene fragment failed, both from plasmid solution containing the gene of interest and from environmental samples.

The mean abundance of the Cu-resistance gene cusA was relatively stable and close to 105 copies g-1 $d w$ in the REF sediments throughout the experiment (Fig. 4a). In Cu-exposed sediments, cusA abundance slightly decreased between d0 (3.4 $105 \pm 2.1105$ copies g-1 dw) and Day 21 (3.7 104 \pm 1.3 104 copies g- $1 \mathrm{dw}$ ) with no significant difference between REF and CU treatments (Fig. 4a). However, and because of a marked decrease in the abundance of the 16Sr RNA gene in CU communities (from about 8106 copies g-1 dw at Day 0 to about 5105 copies g-1 dw at Day 21; data not shown), the relative abundance of cusA (expressed as \% of number of $16 \mathrm{~S}$ rRNA gene copies) gradually increased from Day $0(4.1 \pm 0.3 \%)$ to Day $21(8.6 \pm 3.1 \%)$, while it remained relatively stable between $4.2 \%$ and $6.1 \%$ in REF communities (Fig. 4b). The relative abundance of cusA was about 1.5 times higher in CU than in REF from Day 7 to Day 21, the difference being significant only at Day $14(p<0.05)$.

Fig. 4. Abundance (copy g-1 dw; $A, C, E$ ) and relative abundance (\% $16 \mathrm{~S}$ rRNA gene; $B, D, F)$ of cusA ( $A, B)$, ars $B$ (C, D) and $\operatorname{acr} 3(E, F)$ analyzed by quantitative real-time PCR in uncontaminated (REF) and Cu-spiked (CU) sediments at Days 0 (i.e. $20 \mathrm{~h}$ after spiking), 7, 14 and 21. For each sampling time, asterisks indicate significant differences between treatments $(* p<0.05 ; * * p<0.01 ; * * *<0.001)$.
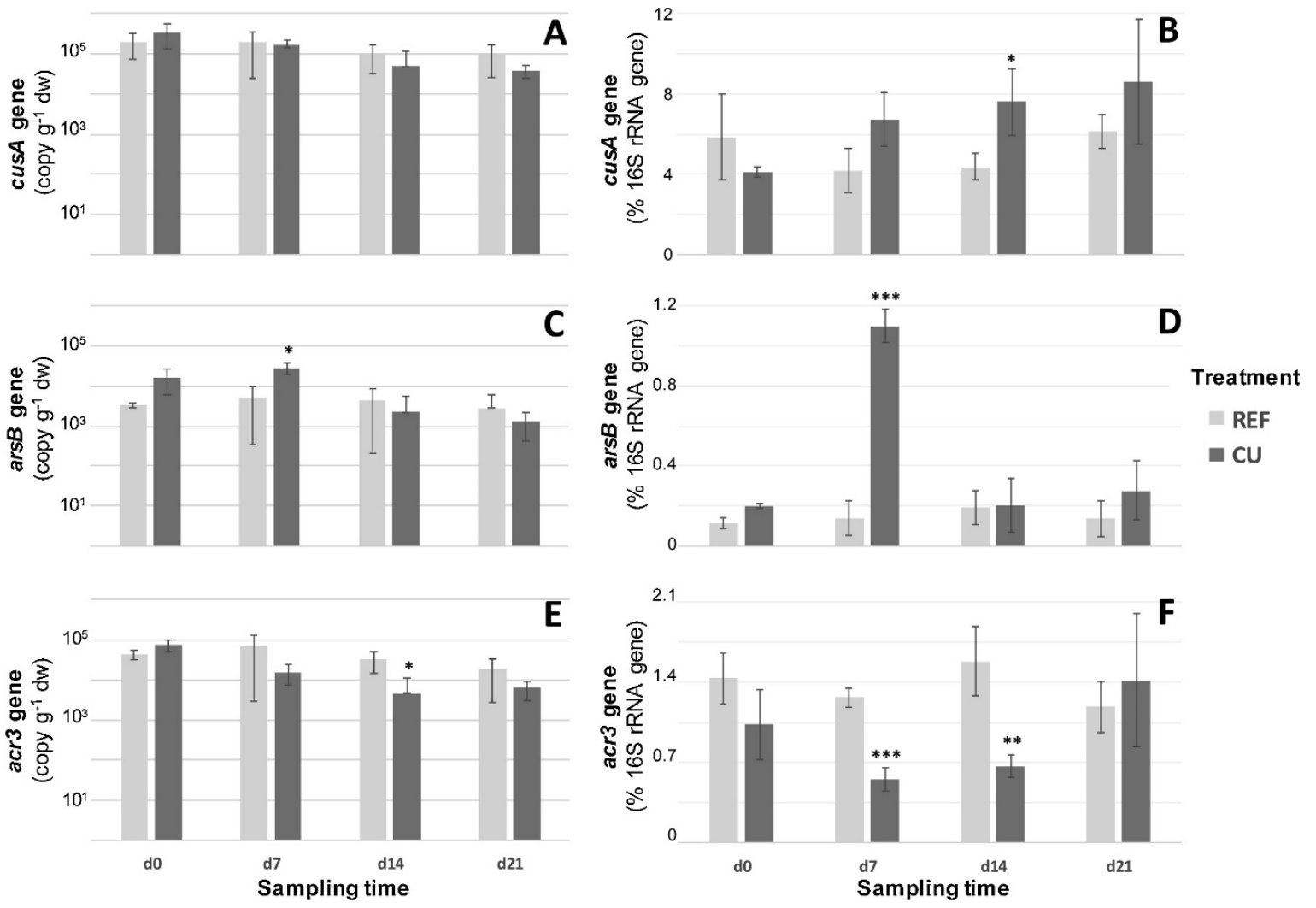

In the REF communities, the mean abundances of the As-resistance genes arsB (2.8 103-5.1 103; Fig. 4b) and acr3 (1.9 104-6.7 104; Fig. 4c) were also relatively stable between Day 0 and Day 21. Chronic $\mathrm{Cu}$ exposure had limited and sporadic effects on these abundance levels, resulting in a significant increase in the copy number of $\operatorname{ars} B$ at $d 7(p<0.05)$ and a decrease in the copy number of acr3 at Day 14 ( $p<0.05)$. These effects were also visible and more significant for relative abundances according to the number of $16 \mathrm{~S}$ rRNA gene copies (Fig. $4 \mathrm{~d}$ and $4 \mathrm{f}$ ). The mean relative abundance of arsB was about 8 times higher in CU $(1.10 \pm 0.08 \%)$ than in REF $(0.14 \pm 0.09 \%)$ at Day $14(p<0.001)$ and the mean relative abundance of acr3 was about 2 times lower in $\mathrm{CU}(<0.7 \%)$ than in REF (>1.2\%) at both Day 7 $(p<0.001)$ and Day $14(p<0.01)$. 


\subsection{Effect of chronic exposure to $\mathrm{Cu}$ on community tolerance to acute toxicity of $\mathrm{Cu}$ and As}

The dose-response curves describing the acute toxicity effects of $\mathrm{Cu}$ and As on the tested extracellular enzymatic activities are given in Fig. 5, Fig. 6, respectively, and the derived EC50 values are reported in Table 1.

Fig. 5. Modeled dose-response curves (and 95\% confidence interval) obtained after shortterm $(4 \mathrm{~h})$ toxicity tests of $\mathrm{Cu}$ on $\beta$-glucosidase (a), leucine aminopeptidase (b) and phosphatase (c) activities in sediment microbial communities collected on Day 21 in uncontaminated (REF) and Cu-spiked (CU) treatments.

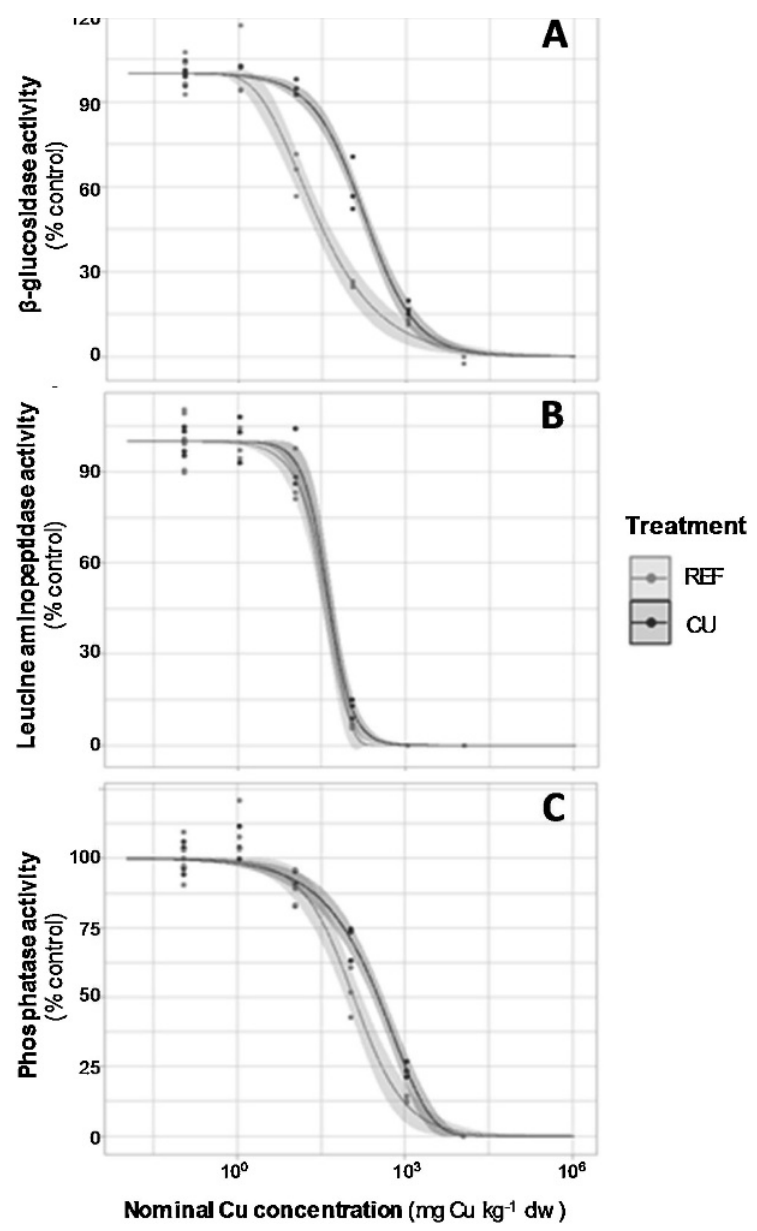

Fig. 6. Modeled dose-response curves (and confidence interval 95\%) obtained after shortterm $(4 \mathrm{~h})$ toxicity tests of As on $\beta$-glucosidase

(a) and leucine aminopeptidase (b) activities in sediment microbial communities collected on Day 21 in uncontaminated (REF) and Cu-spiked (CU) treatments.

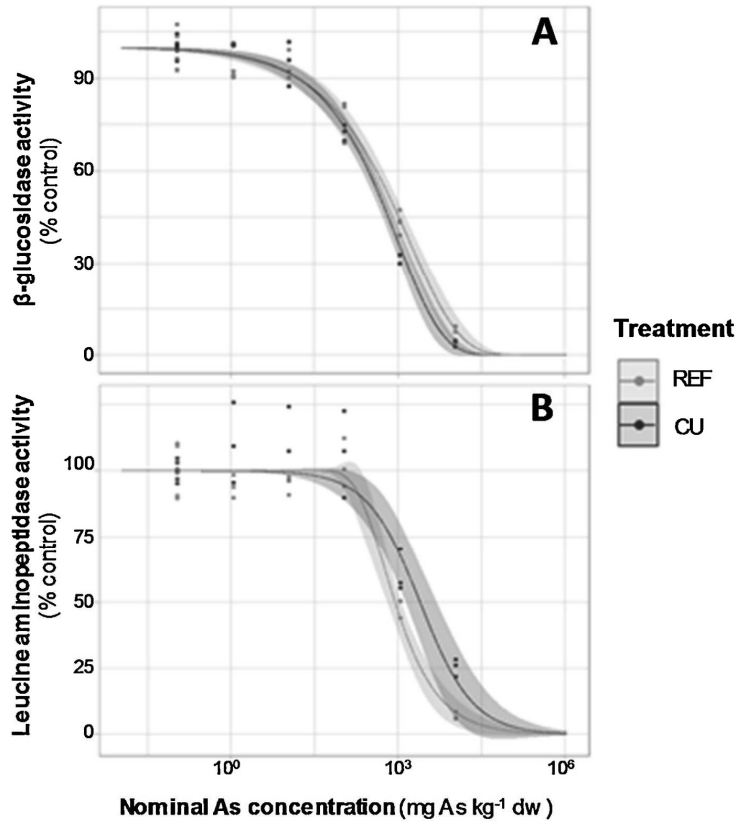

Short-term toxicity tests performed using the Pase activity revealed no effect of As on this parameter in our experimental conditions (data not shown). Accordingly, no response curves were modeled and no EC50 values were determined in this case.

Whichever the activity considered ( $\beta$-Glu or Lap), short-term exposure of REF communities to $\mathrm{Cu}$ resulted in EC50 values (about 25 and $38 \mathrm{mg} \mathrm{kg-1} \mathrm{dw} \mathrm{for} \beta$-Glu and Lap) more than 20 times lower than those obtained following short-term exposure to As (about 519 and $2486 \mathrm{mg} \mathrm{kg-1} \mathrm{dw} \mathrm{for} \beta$-Glu and Lap) (Table 1). 
Table 1. EC50 values (mg kg-1 dw) and confidence intervals $95 \%$ (in parentheses) determined from doseresponse curves illustrated in Fig. 4, Fig. 5. Non-overlapping confidence intervals of the EC50 estimates identify significantly higher EC50 values in the CU treatment (in bold) than in the REF treatment. nd: not determined (due to the lack of short-term toxicity of As on the phosphatase activity).

\begin{tabular}{|c|c|c|c|c|}
\hline & \multicolumn{2}{|c|}{$\begin{array}{l}\text { Cu acute toxicity } \\
\left(\mathrm{EC}_{50} ; \mathrm{mg} \mathrm{Cu} \mathrm{kg}^{-1} \mathrm{dw}\right)\end{array}$} & \multicolumn{2}{|l|}{$\begin{array}{l}\text { As acute toxicity } \\
\left(\mathrm{EC}_{50} ; \mathrm{mg} \mathrm{As} \mathrm{kg}^{-1} \mathrm{dw}\right)\end{array}$} \\
\hline & REF & CU & REF & CU \\
\hline \multirow[t]{2}{*}{$\beta$-glucosidase } & 24.5 & 177.5 & $774.3(549.6-999.0)$ & $519.5(401.0-638.0)$ \\
\hline & $(16.4-32.5)$ & $(142.6-212.5)$ & & \\
\hline \multirow[t]{2}{*}{ leucine aminopeptidase } & 38.0 & $40.3(30.6-49.9)$ & $884.7(640.8-1128.7)$ & 2485.7 \\
\hline & $(28.1-47.9)$ & & & $(1325.6-4661.3)$ \\
\hline \multirow[t]{2}{*}{ phosphatase } & 121.5 & 335.0 & nd & nd \\
\hline & $(80.0-163.0)$ & $(251.8-418.1)$ & & \\
\hline
\end{tabular}

At Day 21, the tolerance levels to $\mathrm{Cu}$ acute toxicity were higher in $\mathrm{CU}$ communities than in REF communities when considering $\beta$-Glu (Fig. 5a) and Pase (Fig. 5c) activities as endpoints. Compared to REF samples, EC50 values obtained with CU communities (about 177 and $335 \mathrm{mg} \mathrm{kg-1} \mathrm{dw} \mathrm{for} \beta$-Glu and Lap) were thus about 7 times higher for $\beta$-Glu measurements and 3 times higher for Pase measurements (Table 1). No difference was observed between REF and CU communities when the Lap activity was used as endpoint to estimate tolerance to $\mathrm{Cu}$ acute toxicity (EC50 close to $40 \mathrm{mg} \mathrm{kg}-1 \mathrm{dw}$; Fig. 5b, Table 1).

Tolerance levels to As acute toxicity were similar between $\mathrm{CU}$ and REF communities when toxicity tests were performed on $\beta$-Glu (EC50 close to $774 \mathrm{mg} \mathrm{kg-1} \mathrm{dw;} \mathrm{Fig.} \mathrm{6a,} \mathrm{Table} \mathrm{1).} \mathrm{EC50} \mathrm{values} \mathrm{were}$ significantly higher in CU communities (about $2486 \mathrm{mg} \mathrm{kg}-1 \mathrm{dw}$ ) than in REF communities (about 885 mg kg-1 dw) when As acute toxicity was estimated using the Lap activity as endpoint (Fig. 6b, Table 1).

\section{Discussion}

\subsection{Cu-induced changes in bacterial and archaeal community structure and composition increased Cu tolerance at community level}

Using the ARISA genetic fingerprinting technique, we had previously shown that the tested scenario of chronic exposure to $\mathrm{Cu}$ significantly impacted bacterial community structure from Day 7 to Day 21 (Mahamoud Ahmed et al., 2018). Similar effects of Cu on bacterial sediment community structure have already been reported (Gillan, 2004; Zhao et al., 2014), but almost nothing is known about the associated changes in bacterial diversity and composition (Yang et al., 2018; Sutcliffe et al., 2019). This was also recently reported by Corcoll et al. (2019) for microbial periphytic communities. Consistent with the results they obtained with this type of microbial assemblage (Corcoll et al., 2019), we observed in the present study a significant negative effect of chronic $\mathrm{Cu}$ exposure on $16 \mathrm{~S}$ rRNA genebased diversity (including bacteria and archaea), as shown by the significant decrease in both the number of OTUs and the Shannon diversity index (Fig. 1). This is in line with the study conducted by Sutcliffe et al. (2019), who showed that exposure to a gradient of $\mathrm{Cu}$ (from about 46 to $487 \mathrm{mg} \mathrm{kg}$-1) led to a dose-dependent decrease in the diversity of the bacterial and archaeal benthic community. As mentioned by McTee et al. (2019), richness decrease upon copper addition can both be due to the disappearance of some species that could not tolerate the $\mathrm{Cu}$ concentration or that had no sufficient time to adapt. 
In the present work, the important diversity loss suggests that $\mathrm{Cu}$ created a strong habitat filter for the microbial community (McTee et al., 2019). Further to the recent work of Sutcliffe et al. (2019), who investigated only long-term effects, we observed a very rapid decrease in diversity metrics following Cu exposure (Fig. 1). Though more pronounced from Day 7 to Day 14 ( $p<0.01$ or $p<0.001$ according to sampling time and diversity parameter), this decrease was also detectable at Day 0, i.e. only $20 \mathrm{~h}$ after $\mathrm{Cu}$ spiking $(\mathrm{p}<0.05)$. This suggests that the first negative effects of $\mathrm{Cu}$ on community diversity may have occurred immediately after sediment spiking (i.e. during the $6 \mathrm{~h}$ stirring procedure and the overnight decantation) and before the setting-up of the artificial channels. This hypothesis was also previously advanced for several functional effects (inhibition of the $\beta$-Glu, Lap and Pase activities and denitrification), but the ARISA approach then used did not allow the detection of structural changes in the $\mathrm{Cu}$-exposed bacterial communities at Day 0 because of the lower methodological resolution (Mahamoud Ahmed et al., 2018; Table 2). In the present study, Day 0 communities from the REF and CU treatments already clustered out on the NMDS analysis (Fig. 2). This confirms that even if fingerprinting methods remain legitimate approaches to correlate environmental variables with microbial community structure (van Dorst et al., 2014), high-throughput rRNA gene sequencing offers a powerful tool to more finely assess ecotoxicological effects on the diversity, structure and composition of these communities, including those associated with sediments (Gardham et al., 2014; Yang et al., 2018; Zhang et al., 2018).

Table 2. Summary of the main observed effects of $\mathrm{Cu}$ on microbial communities in the present study and in the study of Mahamoud Ahmed et al. (2018) during A) the first $20 \mathrm{~h}$ of chronic exposure (i.e. before the setting-up of the artificial channels, during the 6 -h stirring procedure and the overnight decantation after the initial sediment spiking procedure), B) the 21 days of chronic exposure in artificial channels, and C) the $4 \mathrm{~h}$ of acute exposure (i.e. during the short-term toxicity tests performed at D21).

[p.s.] present study; [M.A.] Mahamoud Ahmed et al., 2018; $\searrow$ significant decrease $(p<0.05)$; = no significant effect ( $p>0.05)$; nd not determined.

\begin{tabular}{|c|c|c|c|}
\hline & A & B & C \\
\hline Exposure duration & $\begin{array}{c}\text { First } 20 \text { hours of the chronic } \\
\text { exposure (d0) }\end{array}$ & $\begin{array}{l}21 \text { days of chronic exposure } \\
\text { (d7 to d21) }\end{array}$ & $\begin{array}{c}4 \text { hours of acute } \\
\text { exposure }\end{array}$ \\
\hline $\begin{array}{l}\text { Nominal } \\
\text { concentrations }\end{array}$ & $40 \mathrm{mg} \mathrm{Cu} \mathrm{kg}^{-1} \mathrm{dw}$ & $40 \mathrm{mg} \mathrm{Cu} \mathrm{kg}^{-1} \mathrm{dw}$ & $\begin{array}{l}1.1-1.110^{4} \mathrm{mg} \\
\mathrm{Cu} \mathrm{kg}^{-1} \mathrm{dw}\end{array}$ \\
\hline Communities & $\begin{array}{l}\text { CU-exposed communities in } \\
\text { comparison with REF }\end{array}$ & $\begin{array}{l}\text { CU-exposed communities in } \\
\text { comparison with REF }\end{array}$ & $\begin{array}{l}\text { REF (mean } \\
\text { EC50) }\end{array}$ \\
\hline $\begin{array}{l}\text { Number of } 16 \mathrm{~S} \text { rRNA } \\
\text { gene OTUs }\end{array}$ & $\checkmark[$ p.s. $]$ & $\begin{array}{l}y \text { from } \mathrm{d} 7 \text { to } \mathrm{d} 21 \\
\text { (no recovery) [p.s.] }\end{array}$ & nd \\
\hline $\begin{array}{l}\text { Shannon diversity } \\
\text { index }\end{array}$ & $\checkmark[$ p.s.] & $\begin{array}{l}\mathrm{y} \text { from } \mathrm{d} 7 \text { to } \mathrm{d} 21 \\
\text { (no recovery) [p.s.] }\end{array}$ & nd \\
\hline$\beta$-glu activity & $\triangle(-66 \%)[$ M.A.] & $\begin{array}{c}y \text { from } \mathrm{d} 7 \text { to } \mathrm{d} 21 \\
\text { (no recovery) [M.A.] }\end{array}$ & $\begin{array}{c}24.5 \mathrm{mg} \mathrm{Cu} \mathrm{kg}{ }^{-1} \\
\mathrm{dw}[\text { p.s.] }\end{array}$ \\
\hline Lap activity & $\triangle(-72 \%)$ [M.A.] & $\begin{array}{c}\triangle \text { from d7 to d21 } \\
\text { (no recovery) [M.A.] }\end{array}$ & $\begin{array}{c}38.0 \mathrm{mg} \mathrm{Cu} \mathrm{kg}{ }^{-1} \\
\mathrm{dw}[\mathrm{p} . \mathrm{s} .]\end{array}$ \\
\hline Pase activity & $\triangle(-47 \%)[$ M.A.] & $\begin{array}{c}\Delta \text { from } \mathrm{d} 7 \text { to } 14 \\
=\text { at } \mathrm{d} 21(\text { recovery }) \text { [M.A.] }\end{array}$ & $\begin{array}{l}121.5 \mathrm{mg} \mathrm{Cu} \\
\mathrm{kg}^{-1} \mathrm{dw}[\text { p.s. }]\end{array}$ \\
\hline Denitrification & $\triangle[\mathrm{M} \cdot \mathrm{A}]$ & $\begin{array}{c}y \text { at } \mathrm{d} 14 \\
=\text { at } \mathrm{d} 7 \text { and } \mathrm{d} 21(\text { recovery }) \\
{[\mathrm{M} . \mathrm{A}]}\end{array}$ & nd \\
\hline Respiration & $=[\mathrm{M} . \mathrm{A}]$. & $\begin{array}{c}\text { = at d7 and d14 } \\
y \text { at d21 (delayed effect) [M.A.] }\end{array}$ & nd \\
\hline
\end{tabular}


At the genus scale, some of the significantly more abundantly represented taxa under $\mathrm{Cu}$ exposure were previously identified in the literature as probably resistant to copper (Arenimonas sp., Myung et al., 2018), found in acid mine drainage (Aquabacterium sp., Yang et al., 2008), metal-resistant and exhibiting a metabolism stimulated by copper addition (Methylophilus spp., Kou et al., 2018; Mishra et al., 2018; Semrau et al., 2010) or with copper biosorption and bioaccumulation abilities (Zoogloea spp., Sağ and Kutsal, 1995). Some genera were not previously identified as Cu-resistant, but examination of molecular data banks showed that they were probably harboring copA, copB, copD or cusA resistance genes.

The taxa that were significantly less richly represented under Cu exposure were (i) Cu-sensitive bacteria and archaea directly impacted by the metal toxicity, and (ii) bacteria and archaea indirectly impacted through a reduction of their fitness (i.e. their relative capacities to survive and divide in comparison to those of their interacting competitors; Ghoul and Mitri, 2016) following the Cu-induced changes that modified species interactions and competition within the exposed community (Corcoll et al., 2019). Combined with the development of tolerant taxa, better adapted to the changes that occurred both externally (i.e. environment) and internally (i.e. community), the loss of the most sensitive species during the 21 days of chronic exposure increased the capacity of the whole community to tolerate the acute $\mathrm{Cu}$ toxicity, as shown by the short-term toxicity tests performed on the $\beta$-Glu and Pase activities (Fig. 5a and 5c; Table 1). This finding is in line with the PICT concept (Blanck et al., 1988). Although microbial enzymatic activities, including $\beta$-Glu and Lap activities (Tlili et al., 2010; Faburé et al., 2015; Pesce et al., 2018b) have already been successfully used to detect Cu-induced community tolerance in periphytic communities, the present study is, to our knowledge, the first one to consider these kinds of endpoints in applying PICT on sediment communities. In contrast to the results we obtained with $\beta$ Glu and Lap measurements, PICT was not detected when using Lap as toxicity endpoint (Fig. 5b, Table 1). Differences in PICT response to chronic $\mathrm{Cu}$ exposure according to the microbial heterotrophic activity selected as endpoint have already been pointed out, confirming the need to consider different functional descriptors when using PICT approaches to assess ecotoxicological effects on microbial communities (Tlili et al., 2010; Pesce et al., 2018b).

Besides the importance of the Cu-induced shifts in community structure and composition in driving Cu-induced community tolerance, we also hypothesized that such adaptation at community level could also be due to an increase in the abundance of Cu-resistant genes. The absolute quantification of cusA, which encodes a $\mathrm{Cu}$ membrane transporter efflux pump belonging to the resistance-nodulationdivision (RND) protein family, did not reveal any difference in cusA abundance between REF and CU communities (Fig. 4a). However, when considering the ratio of the number of cusA copies to the number of 16S rRNA gene copies, an increasing trend in the proportion of cusA was observed from Day 7 to Day 21 in chronically Cu-exposed communities in comparison with the REF ones (Fig. 4b). This is consistent with the study of Besaury et al. (2013), who observed a significant increase in the proportion of cusA in Cu-exposed marine sediments, whereas this increase was not detectable when considering the abundance of this gene, despite the very high exposure level (> $1400 \mathrm{~g} \mathrm{Cu} \mathrm{kg-1} \mathrm{dw).} \mathrm{The} \mathrm{increasing}$ trend we observed in the proportion of cusA, which was significant at Day 14 ( $p<0.05)$, suggests that some of the microorganisms that were more abundant in the CU than in the REF treatment harbored this gene, lending them a greater ability to tolerate $\mathrm{Cu}$. Besides the CusA efflux pump, the Cu+transporting CopA P-type ATPase is also a common determinant of copper homeostasis and resistance. The quantification of resistance gene copA using $\mathrm{qPCR}$ is not frequent in the literature, probably because many consensus primer pairs lead to the amplification of a long fragment, not suitable for real-time PCR quantification. A previous study designed and used primers for copA quantification in sediment (Roosa et al., 2014), but we failed to amplify any specific fragment with this procedure. 
Alternatively, copA abundance could have been quantified using the protocol published by Li et al. (2012) and successfully used by other authors (Kang et al., 2018; Zhang et al., 2019; Yin et al., 2017) or using the protocol published by Chen et al. (2020). However, many other mechanisms can be involved

in Cu resistance in Gram-negative bacteria (Alquethamy et al., 2019), among which the CDF family of transport proteins (Moore et al., 2005), the periplasmic multi-copper oxidase CueO (Grass and Rensing, 2001), CopB, an outer membrane protein (Cha and Cooksey, 1991), CopD, an inner membrane protein coupled with the CopC copper-binding protein (Cha and Cooksey, 1993; Hu et al., 2009; Lawton et al., 2016), and also the MerR-family regulator CueR, and CopRS, a two-component regulatory system (Stoyanov et al., 2001; Quintana et al., 2017). Because the HME family is present only in Gram-negative bacteria, we probably underestimated the abundance of Cu-resistant microorganisms here, compared with previous studies that recorded higher abundances of copA than cusA (Besaury et al., 2013; Yin et al., 2017). Moreover, recent literature identified the occurrence of novel resistance genes from soil prokaryotic communities underlying that a part of the resistance mechanisms still remains unknown (Xing et al., 2020).

\subsection{Cu-induced changes in bacterial and archaeal community structure and composition did not increase sensitivity to As acute toxicity}

As expected, and consistent with the PICT concept, changes in the structure and composition of the benthic bacterial and archaeal communities following chronic exposure to $\mathrm{Cu}$ increased community tolerance to the acute toxicity of this metal (Table 1). As discussed above, this suggests that most of the species composing the community that developed under chronic $\mathrm{Cu}$ exposure were tolerant or especially resistant to this metal. These species can nevertheless exhibit different sensitivity levels to other stressors if positive or negative species co-tolerance processes are in play (Vinebrooke et al., 2004). Cu-induced tolerance at community level does not therefore necessarily confer tolerance to other metals. Using a PICT approach based on the use of substrate-induced respiration as a functional parameter in the toxicity tests, Tlili et al. (2011) observed that Cu-exposed heterotrophic periphytic communities became more tolerant to the acute toxicity of $\mathrm{Cu}$ ( $\mathrm{Cu}$-induced tolerance) and $\mathrm{Zn} \mathrm{(Cu-}$ induced positive co-tolerance) but more sensitive to the acute toxicity of As (Cu-induced negative cotolerance). Given this previous result (Tlili et al., 2011), we postulated that chronic Cu exposure in the artificial channels would lead to a decrease in the tolerance level of the exposed heterotrophic communities to As. This hypothesis was also strengthened by the fact that the chronically Cu-exposed bacterial and archaeal communities in our study exhibited lower biodiversity than the non-exposed ones (Fig. 1), potentially increasing their sensitivity to further stress according to the ecological insurance concept postulating that biodiversity contributes to maintain ecological functioning under changing environmental stress conditions (Yachi and Loreau, 1999).

As previously observed by Tlili et al. (2011) with the measurement of substrate-induced respiration, the acute toxicity tests we performed on both $\beta$-Glu and Lap activities showed that As was far less toxic than $\mathrm{Cu}$ (Table 1). However, and at variance with both their results and our expectations, the chronically Cu-exposed communities exhibited similar or higher tolerance levels to As than the REF communities when considering the $\beta$-Glu or the Lap activity, respectively. As stated above concerning the induced tolerance to $\mathrm{Cu}$, the interpretation can vary according to the functional parameter used in the toxicity test. Whereas EC50 values derived from $\beta$-Glu measurements suggest that chronic $\mathrm{Cu}$ exposure had no effect on the capacity of the community to tolerate subsequent exposure to As, those derived from Lap measurements suggest co-tolerance processes. 
The $\mathrm{Cu}$ toxicity tests performed on the Lap activity did not reveal any increase in Cu tolerance, in accordance with the PICT concept (whereas an increase in tolerance was shown when using the $\beta$-Glu and Pase activities). This result suggests that resistance to $\mathrm{Cu}$ and $\mathrm{As}$ is probably supported by different species, exhibiting different metabolic capacities. Thus chronic $\mathrm{Cu}$ exposure increased the tolerance of microbial $\beta$-Glu and Pase to $\mathrm{Cu}$ and of microbial Lap to As, but did not influence the resistance of microbial Lap to $\mathrm{Cu}$ or microbial $\beta$-Glu to As. The Cu-induced positive co-tolerance to As observed from the Lap measurement was not explained by any increase in the absolute or relative abundance of the As-resistance genes arsB and acr3 at Day 21 (Fig.4). This is consistent with the results of Roosa et al. (2014) who observed, in four study sites, no correlation between $\mathrm{Cu}$ concentrations in different sediment fractions and the number of arsB copy numbers. Nevertheless, in CU treatment we observed transient variations in the abundance of acr3 (decrease at Day $7, p<0.05$; increase at Day $14, p<0.05$ ). These effects were more pronounced when considering the relative abundance of the two genes (arsB: Day 7, p < 0.001; acr3: Day 7, p $<0.001$ and Day 14, $p<0.01$ ). To assess the outcome of these effects on the temporal evolution of As tolerance capacity, it would have been useful to conduct weekly acute toxicity tests.

\subsection{Exposure to environmental concentrations of $\mathrm{Cu}$ presents an ecotoxicological risk for sediment microbial community diversity and functions}

Interest in the study of the effects of $\mathrm{Cu}$ sediment contamination on the diversity and functioning of exposed benthic microbial communities has grown in recent years (Gardham et al., 2014, 2015; Zhao et al., 2014; Mahamoud Ahmed et al., 2018; Yang et al., 2018; Zhang et al., 2018; Sutcliffe et al., 2018, 2019). Research has yielded clear scientific evidence that environmental concentrations of $\mathrm{Cu}$ (i.e. tens of $\mathrm{mg} \mathrm{Cu} \mathrm{kg-1)} \mathrm{can} \mathrm{exert} \mathrm{significant} \mathrm{effects} \mathrm{on} \mathrm{benthic} \mathrm{microbial} \mathrm{communities} \mathrm{at} \mathrm{both} \mathrm{short-term}$ (i.e.several hours to several days) and long-term (i.e. several weeks and more) time scales. Further to the study of Mahamoud Ahmed et al. (2018), the present study reveals that the effects of $\mathrm{Cu}$ on benthic microbial diversity and on several heterotrophic functions can be extremely rapid ( $0-20 \mathrm{~h}$ during the spiking procedure and $0-4 \mathrm{~h}$ during the acute toxicity test; Table 2), even at concentrations that can be considered as environmentally relevant. The results of the acute toxicity tests we performed on the REF communities especially highlight the high ecotoxicological risk of $\mathrm{Cu}$ : the acute toxic concentrations (i.e. EC50) determined after only 4 hours of exposure (i.e. $24.5-121.5 \mathrm{mg} \mathrm{kg-1}$, according to the enzymatic activity considered) were in the range of concentrations frequently observed in contaminated sediments, which can largely exceed $100 \mathrm{mg} \mathrm{kg-1}$ (Farag et al., 2007; Ancion et al., 2013). These estimated EC50 values are representative of contamination levels measured in the sediments of many French aquatic ecosystems, where mean and median $\mathrm{Cu}$ concentrations are respectively $48.5 \mathrm{mg} \mathrm{kg}-1$ and $21.7 \mathrm{mg} \mathrm{kg}-1(n=11,072)$ with $10 \%$ of the sediment samples exhibiting concentrations higher than $99.9 \mathrm{mg} \mathrm{kg}-1$ (INERIS, 2010). These relatively low EC50 values can explain the significant inhibition of the three measured enzymatic activities (from $47 \%$ to $72 \%$ according to the activity) observed by Mahamoud Ahmed et al. (2018) during the first $20 \mathrm{~h}$ after the initial spike (i.e. Day 0 , Table 2). The present high-throughput sequencing approach shows that these previously observed functional effects at Day 0 were associated with a significant decrease in OTU diversity (Fig. 1) together with changes in microbial composition (Fig. 2). As reported by Corcoll et al. (2019), and even though the studied enzymatic activities have been found to be largely redundant in natural microbial communities (Frossard et al., 2012), the effective functional redundancy in the exposed community was not enough to maintain reference activity levels. 
We note that these rapid effects were observed on natural communities previously exposed to very low concentrations of $\mathrm{Cu}(<2 \mathrm{mg} \mathrm{kg}-1)$, probably insufficient for them to adapt to this metal before the spiking procedure. To better understand and predict temporal effects of chronic exposure in contaminated ecosystems, it is thus important to study the adaptation capacities of a community in terms of tolerance, resistance and resilience, along with the resulting costs of such adaptation (Tlili and Montuelle, 2011). The results of the PICT approach used here clearly show an adaptation within the CU communities, which became more tolerant to $\mathrm{Cu}$. However, this increasing tolerance was associated with less microbial diversity, which can be viewed as an adaptation cost. The resulting structural changes lasted throughout the experiment, revealing a lack of structural recovery, as observed by Sutcliffe et al. (2019) following long-term exposure. Through functional redundancy processes, and possible physiological and metabolic adaptation, functional recovery was observed at the end of the experiment (Day 21) but only for the Pase activity and denitrification and not for $\beta$-Glu and Lap activities (Mahamoud Ahmed et al., 2018; Table 2). Moreover, a significant inhibition of the microbial respiration was observed only at Day 21 (Mahamoud Ahmed et al., 2018; Table 2). These functional effects can be considered as functional costs of adaptation. Besides possible long-term harm to ecosystem functioning, such structural and functional effects can increase the sensitivity of the microbial communities to further chemical or non-chemical stress. Although our results suggest this is not the case for As, increased sensitivity towards other contaminants or physical stress, such as droughts or heat waves, cannot be excluded and needs further research.

\section{Conclusions}

Using $\mathrm{Cu}$ as model substance, the present study is one of the first to report community tolerance acquisition processes in sediment microbial communities subjected to a realistic chronic exposure. Our findings suggest that tolerance measurements, using the PICT approach, could be deployed in situ to assess the ecological effect of $\mathrm{Cu}$, or of other metals, in the sediment compartment of contaminated aquatic ecosystems. In addition, the high-throughput sequencing of the 16S ribosomal rRNA gene showed (i) that the Cu-induced tolerance was mainly due to changes in the bacterial and archaeal community composition and (ii) that it was combined with a loss of microbial diversity. The Cu-induced tolerance was associated with adaptation costs that reduced community diversity and functional potential. At the microbial community level, our findings confirm that laboratory tools such as PICT can usefully serve to assess ecotoxicological impacts and can reveal underlying negative effects such as loss of biodiversity and functional impairment. Ultimately, these underlying negative effects can increase the sensitivity of the tolerant communities to subsequent stresses including toxic ones.

Cu-induced changes did not increase sensitivity to acute As toxicity: Cu-exposed communities exhibited tolerance levels to As that were similar to or higher than those of non-exposed communities, depending on the heterotrophic activity selected as functional endpoint for toxicity testing. Induced tolerance to $\mathrm{Cu}$ and As thus seems to be supported by different species with different metabolic capacities. Further research on the influence of both PICT and positive and negative co-tolerance processes on the functional response of microbial communities to contaminants is now needed to improve ecological risk assessment in a context of multiple stresses and to understand the ecological effects of cumulative or successive exposure to chemical or non-chemical stresses. 


\section{Credit author statement}

$C B, E L$, and $S P$, conceived and designed the study. AMA performed the experiments and samplings. $A M A, C B, P B$, and $E L$ analyzed the samples. VT conducted the bioinformatic and biostatistical analyses. $\mathrm{VT}, \mathrm{EL}$, and SP drafted the manuscript. All coauthors analyzed and interpreted the data, and approved the final submitted version of the manuscript.

\section{Declaration of interests}

The authors declare that they have no known competing financial interests or personal relationships that could have appeared to influence the work reported in this paper.

\section{Acknowledgments}

The authors thank Bernadette Volat, Christophe Rosy, Bernard Motte and Anaïs Charton from the Irstea Aquatic Microbial Ecotoxicology lab for their help in experimental setup and microbial analysis. Thanks are also due to the staff of the Water Chemistry Laboratory (LAMA) of Irstea for nutrient and organic matter analysis, and especially Aymeric Dabrin and Josiane Gahou for $\mathrm{Cu}$ and As analysis, and to Jérôme Jeandenand (CARRTEL) for DNA extraction. Ayanleh Mahamoud Ahmed was funded by a $\mathrm{PhD}$ grant from the government of Djibouti. This research was partially funded by a grant from the Université Savoie Mont Blanc(MITOX Project) and a grant from the French Agency for Biodiversity(AFB; Irstea-AFB action \#46, 2017-2018).

\section{References}

Akaike, H., 1974. A new look at the statistical model identification. IEEE Trans. Automat.Contr. 19, 716-723. https://doi.org/10.1109/TAC.1974.1100705.

Alquethamy, S.F., Khorvash, M., Pederick, V.G., Whittall, J.J., Paton, J.C., Paulsen, I.T., Hassan, K.A., McDevitt, C.A., Eijkelkamp, B.A., 2019. The role of the CopA copper efflux system in Acinetobacter baumannii virulence. Int. J. Mol. Sci. 20, 575. https://doi.org/10.3390/ijms20030575.

Altschul, S.F., Gish, W., Miller, W., Myers, E.W., Lipman, D.J., 1990. Basic local alignment search tool. J. Mol. Biol. 215, 403-410. https://doi.org/10.1016/S0022-2836(05)80360-2.

Ancion, P.Y., Lear, G., Dopheide, A., Lewis, G.D., 2013. Metal concentrations in stream biofilm and sediments and their potential to explain biofilm microbial community structure. Environ. Pollut. 173, 117-124. https://doi.org/10.1016/j.envpol.2012.10.012.

Besaury, L., Bodilis, J., Delgas, F., Andrade, S., De la Iglesia, R., Ouddane, B., Quillet, L., 2013. Abundance and diversity of copper resistance genes cusA and copA in microbial communities in relation to the impact of copper on Chilean marine sediments. Mar. Pollut. Bull. 67, 16-25. https://doi.org/10.1016/j.marpolbul.2012.12.007.

Billard, E., Domaizon, I., Tissot, N., Arnaud, F., Lyautey, E., 2015. Multi-scale heterogeneity of Archaeal, Bacterial, methanogens and methanotrophs microbial community structures of lake sediments. Hydrobiologia 751, 159-173. https://doi.org/10.1007/s10750-015-2184-6.

Blanck, H., Dahl, B., 1996. Pollution-induced community tolerance (PICT) in marine periphyton in a gradient of tri-n-butyltin (TBT) contamination. Aquat. Toxicol. 35, 59-77. https://doi.org/10.1016/0166445X(96)00007-0.

Blanck, H., Wängberg, S., Molander, S., 1988. Pollution-induced community tolerance - a new ecotoxicological tool. In: Cairns, J.J., Pratt, J.R. (Eds.), Functional Testing of Aquatic Biota for Estimating Hazards of Chemicals. American Society for Testing and Materials, Philadelphia, pp. 219-230.

Bolger, A.M., Lohse, M., Usadel, B., 2014. Trimmomatic: a flexible trimmer for Illumina sequence data. Bioinformatics 30, 2114-2120. https://doi.org/10.1093/bioinformatics/btu170.

Sources and origins of heavy metals. In: Bradl, H.B. (Ed.), Heavy Metals in the Environment: Origin, Interaction and Remediation. Elsevier, London, pp. 1-27.

Bruins, M.R., Kapil, S., Oehme, F.W., 2000. Microbial resistance to metals in the environment. Ecotoxicol. Environ. Saf. 45, 198-207. https://doi.org/10.1006/eesa.1999.1860.

Cébron, A., Norini, M.P., Beguiristain, T., Leyval, C., 2008. Real-Time PCR quantification of PAH-ring hydroxylating dioxygenase (PAH-RHD $\alpha$ ) genes from Gram positive and Gram negative bacteria in soil and sediment samples. J. Microbiol. Methods 73,148-159. https://doi.org/10.1016/j.mimet.2008.01.009. 
Cha, J.S., Cooksey, D.A., 1991. Copper resistance in Pseudomonas syringae mediated by periplasmic and outer membrane proteins. Proc. Natl. Acad. Sci. U. S. A. 88, 8915-8919. https://doi.org/10.1073/pnas.88.20.8915.

Cha, J.S., Cooksey, D.A., 1993. Copper hypersensitivity and uptake in Pseudomonas syringae containing cloned components of the copper resistance operon. Appl. Environ. Microbiol. 59, 1671-1674.

Chen, J., Zhang, H., Li, J., Liu, Y., Shi, W., Hu, H., 2020. The toxic factor of copper should be adjusted during the ecological risk assessment for soil bacterial community. Ecol. Indic. 111, 106072. https://doi.org/10.1016/j.ecolind.2020.106072.

Conover, W.J., Johnson, M.E., Johnson, M.M., 1981. A comparative study of tests for homogeneity of variances, with applications to the outer continental shelf bidding data. Am. Stat. 35, 351-361. https://doi.org/10.2307/1268225.

Corcoll, N., Yang, J., Backhaus, T., Zhang, X., Eriksson, K.M., 2019. Copper affects composition and functioning of microbial communities in marine biofilms at environmentally relevant concentrations. Front. Microbiol. 9, 3248. https://doi.org/10.3389/fmicb.2018.03248.

de Klein, J.J.M., Overbeek, C.C., Juncher Jørgensen, C., Veraart, A.J., 2017. Effect of temperature on oxygen profiles and denitrification rates in freshwater sediments. Wetlands 37, 975-983. https://doi.org/10.1007/s13157-017-0933-1.

Escudié, F., Auer, L., Bernard, M., Mariadassou, M., Cauquil, L., Vidal, K., Maman, S., Hernandez-Raquet, G., Combes, S., Pascal, G., 2018. FROGS: find, rapidly, OTUs with Galaxy solution. Bioinformatics 34, $1287-$ 1294. https://doi.org/10.1093/bioinformatics/btx791.

Faburé, J., Dufour, M., Autret, A., Uher, E., Fechner, L.C., 2015. Impact of an urban multimetal contamination gradient: metal bioaccumulation and tolerance of river biofilms collected in different seasons. Aquat. Toxicol. 159, 276-289. https://doi.org/10.1016/j.aquatox.2014.12.014.

Farag, A.M., Woodward, D.F., Goldstein, J.N., Brumbaugh, W., Meyer, J.S., 1998. Concentrations of metals associated with mining waste in sediments, biofilm, benthic macroinvertebrates, and fish from the Coeur d'Alene River Basin, Idaho. Arch. Environ. Contam. Toxicol. 34, 119-127. https://doi.org/10.1007/s002449900295.

Farag, A.M., Nimick, D.A., Kimball, B.A., Church, S.E., Harper, D.D., Brumbaugh, W.G., 2007. Concentrations of metals in water, sediment, biofilm, benthic macroinvertebrates, and fish in the Boulder River watershed, Montana, and the role of colloids in metal uptake. Arch. Environ. Contam. Toxicol. 52, 397409. https://doi.org/10.1007/s00244-005-0021-z.

Foulquier, A., Volat, B., Neyra, M., Bornette, G., Montuelle, B., 2013. Long-term impact of hydrological regime on structure and functions of microbial communities in riverine wetland sediments. FEMS Microbiol. Ecol. 85, 211-226. https://doi.org/10.1111/1574-6941.12112.

Franke, S., Grass, G., Rensing, C., Nies, D.H., 2003. Molecular analysis of the copper transporting efflux system CusCFBA of Escherichia coli. J. Bacteriol. 185, 3804-3812.

Frossard, A., Gerull, L., Mutz, M., Gessner, M.O., 2012. Disconnect of microbial structure and function: enzyme activities and bacterial communities in nascent stream corridors. ISME J. 6, 680-691. https://doi.org/10.1038/ismej.2011.134.

Gardham, S., Hose, G.C., Stephenson, S., Chariton, A.A., 2014. DNA metabarcoding meets experimental ecotoxicology: advancing knowledge on the ecological effects of copper in freshwater ecosystems. Adv. Ecol. Res. 51, 79-104. https://doi.org/10.1016/B978-0-08-099970-8.00007-5.

Gardham, S., Chariton, A.A., Hose, G.C., 2015. Direct and indirect effects of copper contaminated sediments on the functions of model freshwater ecosystems. Ecotoxicology 24, 61-70. https://doi.org/10.1007/s10646-014-1355-y.

Ghattas, A.K., Fischer, F., Wick, A., Ternes, T.A., 2017. Anaerobic biodegradation of (emerging) organic contaminants in the aquatic environment. Water Res. 116, 268-295. https://doi.org/10.1016/j.watres.2017.02.001.

Ghoul, M., Mitri, S., 2016. The ecology and evolution of microbial competition. Trends Microbiol. 24, 833845. https://doi.org/10.1016/j.tim.2016.06.

Gillan, D.C., 2004. The effect of an acute copper exposure on the diversity of a microbial community in North Sea sediments as revealed by DGGE analysis the importance of the protocol. Mar. Poll. Bull. 49, 504-513. https://doi.org/10.1016/j.marpolbul.2004.03.003.

Grass, G., Rensing, C., 2001. CueO is a multi-copper oxidase that confers copper tolerance in Escherichia coli. Biochem. Biophys. Res. Commun. 286, 902-908. https://doi.org/10.1006/bbrc.2001.5474. 
Hu, Y.H., Wang, H.L., Zhang, M., Sun, L., 2009. Molecular analysis of the copper-responsive CopRSCD of a pathogenic Pseudomonas fluorescens strain. J. Microbiol. 47,277-286. https://doi.org/10.1007/s12275008-0278-9.

INERIS, 2010. Qualité chimique des sédiments fluviaux en France. Synthèse des bases de données disponibles. Rapport d'étude. N INERIS-DRC-10-105335-04971A. 99 p.

Kang, W., Zhang, Y.J., Shi, X., He, J.Z., Hu, H.W., 2018. Short-term copper exposure as a selection pressure for antibiotic resistance and metal resistance in an agricultural soil. Environ. Sci. Pollut. Res. 25, 2931429324. https://doi.org/10.1007/s11356-018-2978-y.

Kou, S., Vincent, G., Gonzalez, E., Pitre, F.E., Labrecque, M., Brereton, N.J.B., 2018. The response of a 16S ribosomal RNA gene fragment amplified community to Lead, Zinc, and Copper pollution in a Shanghai field trial. Front. Microbiol. 9, 366. https://doi.org/10.3389/fmicb.2018.00366.

Kozich, J.J., Westcott, S.L., Baxter, N.T., Highlander, S.K., Schloss, P.D., 2013. Development of a dual-index sequencing strategy and curation pipeline for analyzing amplicon sequence data on the miseq illumina sequencing platform. Appl. Environ. Microbiol. 79, 5112-5120. https://doi.org/10.1128/AEM.01043-13.

Lambert, A.S., Morin, S., Artigas, J., Volat, B., Coquery, M., Neyra, M., Pesce, S., 2012. Structural and functional recovery of microbial biofilms after a decrease in copper exposure: influence of the presence of pristine communities. Aquat. Toxicol. 109, 118-126. https://doi.org/10.1016/j.aquatox.2011.12.006.

Lawton, T.J., Kenney, G.E., Hurley, J.D., Rosenzweig, A.C., 2016. The CopC family: structural and bioinformatics insights into a diverse group of periplasmic copper binding proteins. Biochemistry 55, 2278-2290. https://doi.org/10.1021/acs.biochem.6b00175.

Li, X.F., Yin, H.B., Su, J.Q., 2012. An attempt to quantify Cu-resistant microorganisms in a paddy soil from Jiaxing, China. Pedosphere 22, 201-205. https://doi.org/10.1016/S1002-0160(12)60006-X.

Love, M.I., Huber, W., Anders, S., 2014. Moderated estimation of fold change and dispersion for RNA-seq data with DESeq2. Genome Biol. 15, 550. https://doi.org/10.1186/s13059-014-0550-8.

Lozupone, C., Knight, R., 2005. UniFrac: a new phylogenetic method for comparing microbial communities. Appl. Environ. Microbiol. 71, 8228-8235. https://doi.org/10.1128/AEM.71.12.8228.

MacDonald, D.D., Ingersoll, C.G., Berger, T.A., 2000. Development and evaluation of consensus-based sediment quality guidelines for freshwater ecosystems. Arch. Environ. Contam. Toxicol. 39, $20-31$. https://doi.org/10.1007/s002440010075.

Magoč, T., Salzberg, S.L., 2011. FLASH: fast length adjustment of short reads to improve genome assemblies. Bioinformatics 27, 2957-2963. https://doi.org/10.1093/bioinformatics/btr507.

Mahamoud Ahmed, A., Lyautey, E., Bonnineau, C., Dabrin, A., Pesce, S., 2018. Environmental concentrations of copper, alone or in mixture with arsenic, can impact river sediment microbial community structure and functions. Front. Microbiol. 9, 1852. https://doi.org/10.3389/fmicb.2018.01852.

Mahé, F., Rognes, T., Quince, C., de Vargas, C., Dunthorn, M., 2015. Swarm v2: highly scalable and highresolution amplicon clustering. PeerJ. 3, e1420. https://doi.org/10.7717/peerj.1420.

McTee, M., Bullington, L., Rillig, M.C., Ramsey, P.W., 2019. Do soil bacterial communities respond differently to abrupt or gradual additions of copper? FEMS Microbiol. Ecol. 95https://doi.org/10.1093/femsec/fiy212. fiy212.

Mishra, V.K., Shukla, R., Shukla, P.N., 2018. Metal uptake potential of four methylotrophic bacterial strains from coal mine spoil, exploring a new possible agent for bioremediation. Environ. Technol. Innov. 11, 174-186. https://doi.org/10.1016/j.eti.2018.05.001.

Moore, C.M., Gaballa, A., Hui, M., Ye, R.W., Helmann, J.D., 2005. Genetic and physiological responses of Bacillus subtilis to metal ion stress. Mol. Microbiol. 57, 27-40. https://doi.org/10.1111/j.13652958.2005.04642.x.

Myung, J., Yang, W., Saikaly, P.E., Logan, B.E., 2018. Copper current collectors reduce long-term fouling of air cathodes in microbial fuel cells. Environ. Sci. - Wat. Res. 4,513-519. https://doi.org/10.1039/C7EW00518K.

Olgivie, L.A., Grant, A., 2008. Linking pollution induced community tolerance (PICT) and microbial community structure in chronically metal polluted estuarine sediments. Mar. Environ. Res. 65, 187-198. https://doi.org/10.1016/j.marenvres.2007.10.002.

Pesce, S., Margoum, C., Foulquier, A., 2016. Pollution-induced community tolerance for in situ assessment of recovery in river microbial communities following the ban of the herbicide diuron. Agric. Ecol. Environ. 221, 79-86. https://doi.org/10.1016/j.agee.2016.01.009. 
Pesce, S., Perceval, O., Bonnineau, C., Casado-Martinez, C., Dabrin, A., Lyautey, E., Naffrechoux, E., Ferrari, B.J.D., 2018a. Looking at biological community level to improve ecotoxicological assessment of freshwater sediments: report on a first French-Swiss workshop. Environ. Sci. Pollut. Res. 25, 970-974. https://doi.org/10.1007/s11356-017-0620-z.

Pesce, S., Lambert, A.S., Morin, S., Foulquier, A., Coquery, M., Dabrin, A., 2018b. Experimental warming differentially influences the vulnerability of phototrophic and heterotrophic periphytic communities to copper toxicity. Front. Microbiol. 9, 1424. https://doi.org/10.3389/fmicb.2018.01424.

Pesce, S., Campiche, S., Casado-Martinez, C., Mahamoud Ahmed, A., Bonnineau, C., Dabrin, A., Lyautey, E., Ferrari, B.J.D., 2020. Towards simple tools to assess functional effects of contaminants on natural microbial and invertebrate sediment communities. Environ. Sci. Pollut. Res. https://doi.org/10.1007/s11356-019-07331-z.

Poirel, J., Joulian, C., Leyval, C., Billard, P., 2013. Arsenite-induced changes in abundance and expression of arsenite transporter and arsenite oxidase genes of a soil microbial community. Res. Microbiol. 164, 457465. https://doi.org/10.1016/j.resmic.2013.01.012.

Quast, C., Pruesse, E., Yilmaz, P., Gerken, J., Schweer, T., Yarza, P., Peplies, J., Glöckner, F.O., 2013. The SILVA ribosomal RNA gene database project: improved data processing and webbased tools. Nucleic Acids Res. 41, 590-596. https://doi.org/10.1093/nar/gks1219.

Quintana, J., Novoa-Aponte, L., Arguello, J.M., 2017. Copper homeostasis networks in the bacterium Pseudomonas aeruginosa. J. Biol. Chem. 292, 15691-15704. https://doi.org/10.1074/jbc.M117.804492.

R Core Team, 2018. A Language and Environment for Statistical Computing. URL. R Foundation for Statistical Computing, Vienna, Austria. https://www.R-project.org/.

Rabiet, M., Coquery, M., Carluer, N., Gahou, J., Gouy, V., 2015. Transfer of metal(loid)s in a small vineyard catchment: contribution of dissolved and particulate fractions in river for contrasted hydrological conditions. Environ. Sci. Pollut. Res. 22, 19224-19239. https://doi.org/10.1007/s11356-015-5079-1.

Ritz, C., Baty, F., Streibig, J.C., Gerhard, D., 2015. Dose-response analysis using R. PLoS One 10, e0146021. https://doi.org/10.1371/journal.pone.0146021.

Rognes, T., Flouri, T., Nichols, B., Quince, C., Mahé, F., 2016. VSEARCH: a versatile open source tool for metagenomics. PeerJ. 4, e2584. https://doi.org/10.7717/peerj.2584.

Roosa, S., Wattiez, R., Prygiel, E., Lesven, L., Billon, G., Gillan, D.C., 2014. Bacterial metal resistance genes and metal bioavailability in contaminated sediments. Environ. Pollut. 189, 143-151. https://doi.org/10.1016/j.envpol.2014.02.031.

Royston, J.P., 1982. An extension of Shapiro and Wilk's W test for normality to large samples. J. R. Stat. Soc. C. Appl. 31, 115-124. https://doi.org/10.2307/2347973.

Sağ, Y., Kutsal, T., 1995. Biosorption of heavy metals by Zoogloea ramigera: use of adsorption isotherms and a comparison of biosorption characteristics. Chem. Eng. J. Biochem. Eng. J. 60, 181-188. https://doi.org/10.1016/0923-0467(95)03014-X.

Scheffczyk, A., Frankenbach, S., Jänsch, S., Römbke, J., 2014. Comparison of the effects of zinc nitratetetrahydrate and tributyltin-oxide on the reproduction and avoidance behavior of the earthworm Eisenia andrei in laboratory tests using nine soils. Appl. Soil Ecol. 83, 253-257. https://doi.org/10.1016/j.apsoil.2014.03.017.

Schwarz, J.I.K., Eckert, W., Conrad, R., 2007. Community structure of Archaea and Bacteria in a profundal lake sediment Lake Kinneret (Israel). Syst. Appl. Microbiol. 30, $239-254$. https://doi.org/10.1016/j.syapm.2006.05.004.

Semrau, J.D., DiSpirito, A.A., Yoon, S., 2010. Methanotrophs and copper. FEMS Microbiol. Rev. 34, 496-531. https://doi.org/10.1111/j.1574-6976.2010.00212.x.

Stoyanov, J.V., Hobman, J.L., Brown, N.L., 2001. CueR (Ybbl) of Escherichia coli is a MerR family regulator controlling expression of the copper exporter CopA. Mol. Microbiol. 39, 502-511. https://doi.org/10.1046/j.1365-2958.2001.02264.x.

Sutcliffe, B., Chariton, A.A., Harford, A.J., Hose, G.C., Greenfield, P., Midgley, D.J., Paulsen, I.T., 2018. Diverse fungal lineages in subtropical ponds are altered by sediment-bound copper. Fungal Ecol. 34, $28-42$. https://doi.org/10.1016/j.funeco.2018.03.003.

Sutcliffe, B., Hose, G.C., Harford, A.J., Midgley, D.J., Greenfield, P., Paulsen, I.T., Chariton, A.A., 2019. Microbial communities are sensitive indicators for freshwater sediment copper contamination. Environ. Pollut. 247, 1028-1038. https://doi.org/10.1016/j.envpol.2019.01.104.

Tlili, A., Montuelle, B., 2011. Microbial pollution-induced community tolerance. In: Amiart-Triquet, C., Rainbow, P.S., Roméo, M. (Eds.), Tolerance to Environmental Contaminants. CRC Press, New York, pp. 65-108. 
Tlili, A., Bérard, A., Roulier, J.L., Volat, B., Montuelle, B., 2010. PO4 3- dependence of the tolerance of autotrophic and heterotrophic biofilm communities to copper and diuron. Aquat. Toxicol. 98, 165-177. https://doi.org/10.1016/j.aquatox.2010.02.008.

Tlili, A., Maréchal, M., Bérard, A., Volat, B., Montuelle, B., 2011. Enhanced cotolerance and co-sensitivity from long-term metal exposures of heterotrophic and autotrophic components of fluvial biofilms. Sci. Total Environ. 409, 4335-4343. https://doi.org/10.1016/j.scitotenv.2011.07.026.

Tlili, A., Bérard, A., Blanck, H., Bouchez, A., Cássio, F., Eriksson, K.M., Morin, S., Montuelle, B., Navarro, E., Pascoal, C., Pesce, S., Schmitt-Jansen, M., Behra, R., 2016. Pollution induced community tolerance (PICT): towards an ecologically relevant risk assessment of chemicals in aquatic systems. Freshw. Biol. 61, 21412151. https://doi.org/10.1111/fwb.12558.

van Dorst, J., Bissett, A., Palmer, A.S., Brown, M., Snape, I., Stark, J.S., Raymond, B., McKinlay, J., Ji, M., Winsley, T., Ferrari, B.C., 2014. Community fingerprinting in a sequencing world. FEMS Microbiol. Ecol. 89, 316-330. https://doi.org/10.1111/1574-6941.12308.

Vinebrooke, R.D., Cottingham, K.L., Norberg, J., Scheffer, M., Dodson, S.I., Maberly, S.C., Sommer, U., 2004. Impacts of multiple stressors on biodiversity and ecosystem functioning: the role of species cotolerance. Oikos 104, 451-457. https://doi.org/10.1111/j.0030-1299.2004.13255.x.

Wang, Y., Qian, P.Y., 2009. Conservative fragments in bacterial 16S rRNA genes and primer design for $16 \mathrm{~S}$ ribosomal DNA amplicons in metagenomic studies. PLoS One 4, e7401. https://doi.org/10.1371/journal.pone.0007401.

Wang, X., Zang, S., 2014. Distribution characteristics and ecological risk assessment of toxic heavy metals and metalloid in surface water of lakes in Daqing Heilongjiang Province, China. Ecotoxicology 23, 609617. https://doi.org/10.1007/s10646-014-1177-y.

Wu, B., Wang, G., Wu, J., Fu, Q., Liu, C., 2014. Sources of heavy metals in surface sediments and an ecological risk assessment from two adjacent plateau reservoirs. PLoS One 9, e102101. https://doi.org/10.1371/journal.pone.0102101.

Xing, C., Chen, J., Zheng, X., Chen, L., Chen, M., Wang, L., Li, X., 2020. Functional metagenomics exploration identifies novel prokaryotic copper resistance genes from the soil microbiome. Metallomics. https://doi.org/10.1039/C9MT00273A.

Yachi, S., Loreau, M., 1999. Biodiversity and ecosystem productivity in a fluctuating environment: the insurance hypothesis. Proc. Nat. Acad. Sci. U. S. A. 96, 1463-1468. https://doi.org/10.1073/pnas.96.4.1463.

Yang, Y., Shi, W., Wan, M., Zhang, Y., Zou, L., Huang, J., Qiu, G., Liu, X., 2008. Diversity of bacterial communities in acid mine drainage from the Shen-bu copper mine, Gansu province, China. Electron. J. Biotechnol. 11, 6. https://doi.org/10.2225/vol11-issue1-fulltext-6.

Yang, J., Xie, Y., Jeppe, K., Long, S., Pettigrove, V., Zhang, X., 2018. Sensitive community responses of microbiota to copper in sediment toxicity test. Environ. Toxicol. Chem. 37, 599-608. https://doi.org/10.1002/etc.3980.

Ye, S., Zeng, G., Wu, H., Zhang, C., Liang, J., Dai, J., Liu, Z., Xiong, W., Wan, J., Xu, P., Cheng, M., 2017. Cooccurrence and interactions of pollutants, and their impacts on soil remediation-a review. Crit. Rev. Environ. Sci. Technol. 47, 1528-1553. https://doi.org/10.1080/10643389.2017.1386951.

Ye, S., Zeng, G., Wu, H., Liang, J., Zhang, C., Dai, J., Xiong, W., Song, B., Wu, S., Yu, J., 2019. The effects of activated biochar addition on remediation efficiency of cocomposting with contaminated wetland soil. Resour. Conserv. Recycl. 140, 278-285. https://doi.org/10.1016/j.resconrec.2018.10.004.

Yin, Y., Gu, J., Wang, X., Song, W., Zhang, K., Sun, W., Zhang, X., Zhang, Y., Li, H., 2017. Effects of copper addition on copper resistance, antibiotic resistance genes, and intl1 during swine manure composting. Front. Microbiol. 8, 344. https://doi.org/10.3389/fmicb.2017.00344.

Zhang, X., Xia, P., Wang, P., Yang, J., Baird, D.J., 2018. Omics advances in ecotoxicology. Environ. Sci. Technol. 52, 3842-3851. https://doi.org/10.1021/acs.est.7b06494.

Zhang, R., Gu, J., Wang, X., Li, Y., Liu, J., Lu, C., Qiu, L., 2019. Response of antibiotic resistance genes abundance by graphene oxide during the anaerobic digestion of swine manure with copper pollution. Sci. Total Environ. 654, 292-299. https://doi.org/10.1016/j.scitotenv.2018.11.094.

Zhao, Y.G., Feng, G., Bai, J., Chen, M., Maqbool, F., 2014. Effect of copper exposure on bacterial community structure and function in the sediments of Jiaozhou Bay, China. World J. Microbiol. Biotechnol. 30, 20332043. https://doi.org/10.1007/s11274-014-1628-x. 